2012

\title{
Does Large-Scale Ocean Circulation Structure Life History Connectivity in Antarctic Toothfish (Dissostichus mawsoni)?
}

Julian Ashford

Old Dominion University

Michael S. Dinniman

Old Dominion University, msd@ccpo.odu.edu

Cassandra Brooks

Allen H. Andrews

Eileen E. Hofmann

Old Dominion University, ehofmann@odu.edu

See next page for additional authors

Follow this and additional works at: https://digitalcommons.odu.edu/ccpo_pubs

Part of the Aquaculture and Fisheries Commons, Marine Biology Commons, and the Oceanography Commons

\section{Repository Citation}

Ashford, Julian; Dinniman, Michael S.; Brooks, Cassandra; Andrews, Allen H.; Hofmann, Eileen E.; Cailliet, Gregor; Jones, Christopher; and Ramanna, Nakul, "Does Large-Scale Ocean Circulation Structure Life History Connectivity in Antarctic Toothfish (Dissostichus mawsoni)?" (2012). CCPO Publications. 82.

https://digitalcommons.odu.edu/ccpo_pubs/82

\section{Original Publication Citation}

Ashford, J., Dinniman, M.S., Brooks, C., Andrews, A.H., Hofmann, E.E., Cailliet, G., . . Ramanna, N. (2012). Does large-scale ocean circulation structure life history connectivity in Antarctic toothfish (Dissostichus mawsoni)? Canadian Journal of Fisheries and Aquatic Sciences, 69(12), 1903-1919. doi: 10.1139/f2012-111 
Authors

Julian Ashford, Michael S. Dinniman, Cassandra Brooks, Allen H. Andrews, Eileen E. Hofmann, Gregor Cailliet, Christopher Jones, and Nakul Ramanna 


\title{
Does large-scale ocean circulation structure life history connectivity in Antarctic toothfish (Dissostichus mawsoni)?
}

\author{
Julian Ashford, Michael Dinniman, Cassandra Brooks, Allen H. Andrews, \\ Eileen Hofmann, Gregor Cailliet, Christopher Jones, and Nakul Ramanna
}

\begin{abstract}
A multidisciplinary approach incorporating otolith chemistry, age data, and numerical Lagrangian particle simulations indicated a single, self-recruiting population of Antarctic toothfish (Dissostichus mawsoni) in the Southeast Pacific Basin (SPB) and Ross Sea, with a life history structured by the large-scale circulation. Chemistry deposited prior to capture along otolith edges demonstrated strong environmental heterogeneity, yet the chemistry in otolith nuclei, deposited during early life, showed no differences. Age data showed only adult fish in catches on the Pacific-Antarctic Ridge in the SPB and structuring of life stages consistent with transport pathways from the northern Ross Sea. Lagrangian particle simulations predicted that early life stages following the flow in the SPB would be transported to areas in the Ross Sea where juveniles are caught, whereas the circulation would facilitate adult movement along the shelf slope and back into the SPB where spawning adults are caught. These results suggest that successfully spawning fish spend only a part of their adult life history in the Ross Sea, areas in the eastern Ross Sea contribute disproportionately to the spawning population, and areas in the southwestern Ross Sea may supply fisheries in the southern Indian Ocean.
\end{abstract}

\begin{abstract}
Résumé : Une approche multidisciplinaire combinant la chimie des otolites, des données sur l'âge et des simulations lagrangiennes du transport de particules indique qu'il n'y aurait qu'une seule population auto-recrutante de légine antarctique (Dissostichus mawsoni) dans le bassin du sud-est du Pacifique (SPB) et la mer de Ross, dont le cycle biologique serait structuré par la circulation à grande échelle. Si la chimie des pourtours d'otolites déposés avant la capture témoigne d'une grande hétérogénéité du milieu ambiant, celle des noyaux d'otolites, déposés dans les premiers stades de la vie des poissons, ne présente aucune variation. Les données sur l'âge n'indiquent que la présence de poissons adultes dans les prises au-dessus de la dorsale Pacifique-Antarctique dans le SPB et une structuration des stades du cycle de vie qui concorde avec des voies de transport issues de la mer de Ross. Les simulations lagrangiennes de particules prédisent que les légines à des stades de vie précoces qui suivent le courant dans le SPB seraient transportées vers des zones de la mer de Ross caractérisées par la prise de juvéniles, alors que la circulation faciliterait le mouvement des adultes le long du talus du plateau pour ensuite retourner dans le SPB où sont capturés des adultes en frai. Ces résultats suggèrent que les poissons qui réussissent à se reproduire passent seulement une partie de leur vie adulte dans la mer de Ross, qu'une part disproportionnée de la population reproductrice provient de régions de l'est de la mer de Ross et que des régions du sud-ouest de la mer de Ross pourraient contribuer aux ressources halieutiques dans le sud de l'océan Indien.
\end{abstract}

[Traduit par la Rédaction]

\section{Introduction}

A life cycle hypothesis for Antarctic toothfish

The well-documented success of spatial refuges in restoring overexploited fish stocks (e.g., Roberts et al. 2001) has fo- cused attention on protecting marine areas as a tool for fisheries management. However, the biology underlying this success has received less emphasis, in particular the spatial structure of individual populations and their life cycles. Yet a marine protected area (MPA), with its extra costs of adminis-

Received 21 March 2012. Accepted 10 September 2012. Published at www.nrcresearchpress.com/cjfas on 7 November 2012.

J2012-0136

Paper handled by Associate Editor Bronwyn Gillanders.

J. Ashford and N. Ramanna. Center for Quantitative Fisheries Ecology, Old Dominion University, 800 West 46th St., Norfolk, VA 23508, USA.

M. Dinniman and E. Hofmann. Center for Coastal Physical Oceanography, Old Dominion University, 4111 Monarch Way, Norfolk, VA 23508, USA.

C. Brooks and G. Cailliet. Moss Landing Marine Laboratories, 8272 Moss Landing Road, Moss Landing, CA 95039, USA.

A.H. Andrews. Moss Landing Marine Laboratories, 8272 Moss Landing Road, Moss Landing, CA 95039, USA; NOAA Fisheries, Pacific Islands Fisheries Science Center, 99-193 Aiea Heights Drive \#417, Aeia, HI 96701, USA.

C. Jones. Antarctic Ecosystem Research Division, NOAA Southwest Fisheries Science Center, 8604 La Jolla Shores Drive, La Jolla, CA 92037, USA.

Corresponding author: Julian Ashford (e-mail: jashford@odu.edu). 
tration and enforcement, will have little effect if it simply redirects fishing effort away from one part of a randomly mixing population to another, or worse, concentrates diffuse effort into an area through which all successfully spawning fish must pass during their life history. Assessing the potential benefits of MPAs, therefore, demands a clear understanding of the population structure and life cycle of species affected.

Recent initiatives by the Commission of the Convention for the Conservation of Antarctic Marine Living Resources (CCAMLR) for a representative system of MPAs in the Southern Ocean include a new proposal for the Ross Sea, where an important fishery for Antarctic toothfish (Dissostichus mawsoni) is managed primarily through spatially explicit catch quotas based on biennial stock assessments. Although still defined as exploratory, landings have increased from 42 tonnes (t) during the 1997-1998 fishing season to $3091 \mathrm{t}$ in 20062007 (CCAMLR 2007), and the catch quota is currently set at $3282 \mathrm{t}$ for the 2011-2012 season. However, declines in the numbers of adults taken by researchers in the McMurdo Sound and their catch per unit effort have been attributed to commercial activity (DeVries et al. 2008), and there is rising concern over the potential impact of fishing on the Ross Sea ecosystem (e.g., Ainley 2010). An MPA in the Ross Sea may help promote spatial management of the fishery, but the potential benefits remain obscured by uncertainty over toothfish population structure and life cycle.

Commercial vessels target toothfish during the austral summer, deploying benthic longlines when the sea ice breaks up enough to provide access to concentrations of juvenile $(<100 \mathrm{~cm}$ total length) and adult toothfish. From December to May, fishing occurs on the continental shelf and slope and on oceanic banks and seamounts in the western Southeast Pacific Basin (SPB) north as far as the Pacific-Antarctic Ridge (Fig. 1). Juvenile toothfish are caught in commercial catches principally on the shelf, including in the southwestern and eastern Ross Sea, whereas adults predominate in catches from deeper water along the slope. In the SPB, where adults also dominate the catch (Hanchet 2010), their gonadosomatic indices increase over the fishing season (e.g., Fenaughty 2006). To explain this, Hanchet et al. (2008) proposed a life cycle (Fig. 1) in which adults move from the Ross Sea north towards the Pacific-Antarctic Ridge to spawn during the austral winter. Using particle tracking simulations based on a circulation model, they hypothesized that early stages are entrained in the circulation in the SPB; some are advected southward or westward to settle in the western Ross Sea or the Balleny Islands and adjacent continental shelf. Large proportions are advected eastward along the Ross Gyre to reach the eastern Ross Sea. Spent adults then return directly to the continental slope in postspawning migrations.

Several lines of evidence are consistent with this hypothesis. Mature adults tagged by researchers in the southwestern Ross Sea have subsequently been caught in the western SPB (Dunn et al. 2007). Moreover, adults become neutrally buoyant when they reach $100 \mathrm{~cm}$ total length (Near et al. 2003) at $\sim 10$ years of age, reducing the energetic cost of large-scale movement. Phyletic evidence, including brain morphology, suggests a life cycle that involves migration (Fenaughty et al. 2008; Eastman and Lannoo 2011). Migration also likely explains high frequencies of adults with low condition factor in the western SPB (Fenaughty et al. 2008); in contrast, juveniles are benthic and negatively buoyant, and recaptures from fishery tagging programs indicate movement on a much reduced scale. Young stages are considered pelagic (Hanchet et al. 2008), and evidence from otolith micro-increments (La Mesa 2007) suggests a long pelagic phase lasting $\sim 21$ months after being spawned (Hanchet et al. 2008). Toothfish are long-lived (up to 39 years; Horn 2002; Brooks et al. 2011) and unusually fecund for a notothenioid, traits consistent with high rates of early mortality associated with advection.

Despite this evidence, a number of points remain unclear in the hypothesis. Many adult fish caught during the fishing season are in areas from where they cannot feasibly migrate to spawn during the austral winter. Further, gonad indices indicate that adults in the Ross Sea do not mature in preparation for a winter spawning migration. More importantly, they are not physiologically adapted for active large-scale movement. Additionally, several studies suggest spatial distributions inconsistent with the idea of direct return migration to benthopelagic feeding areas along the continental slope. Thus, adult toothfish were commonly recovered from the stomachs of sperm whales (Physeter macrocephalus) on board vessels whaling in pelagic waters in the western SPB, suggesting that fish spent a considerable part of their lives relatively close to the surface (Yukhov 1970) and certainly within the sperm whales' dive range of $\sim 1000 \mathrm{~m}$ (e.g., Watwood et al. 2006). Moreover, adult toothfish were recovered from sperm whales in a plume eastward from the western SPB as far as $100^{\circ} \mathrm{W}$ in the Amundsen Sea; stomach contents consisted mainly of small squid, implying that these toothfish were feeding pelagically (Yukhov 1971). More recently, an adult tagged by researchers in the southwestern Ross Sea was recaptured in the Amundsen Sea (Dunn et al. 2007); however, despite a less traumatic tagging method, recapture rates from tagging in the southwestern Ross Sea were considerably lower than for fish tagged by the fishery.

\section{A multidisciplinary approach to test population structure and connectivity}

Hanchet et al.'s (2008) life cycle hypothesis implies that fish along the Pacific-Antarctic Ridge and in the Ross Sea constitute a single population sharing a similar early life history, with connectivity between areas critical to completing the life cycle. Conventionally, measures like meristics, morphometrics, parasites, age structure, and vital rates are often used to test population hypotheses (e.g., Ihssen et al. 1981). Heterogeneity in these measures can usefully indicate spatial structuring, especially in older life stages. However, in species characterized by dispersal during early life, subsequent exposure to different environments can affect the measures, generating heterogeneity that does not reflect underlying population separation. Alternatively, artificial tags are often useful for determining movement, but these are difficult to apply in young stages or in the numbers required to offset mortality, especially in fecund species.

Otolith chemistry, on the other hand, takes advantage of environmental heterogeneity generated by physical forcing. In the Southern Ocean, otolith chemistry successfully distinguished fish exposed to Antarctic Intermediate Water and Circumpolar Deep Water (CDW; Ashford et al. 2005), frontal zones in the Antarctic Circumpolar Current (ACC) separated by the Subantarctic and Polar Fronts (Ashford et al. 2007), and 
Fig. 1. (Upper panel) Map of Southeast Pacific Basin from Hanchet et al. (2008, their fig. 1), showing mean annual depth-averaged circulation. Pale blue area indicates location of Ross Ice Shelf. (Lower panel) Illustration of life cycle hypothesis from Hanchet et al. (2008, their fig. 7).

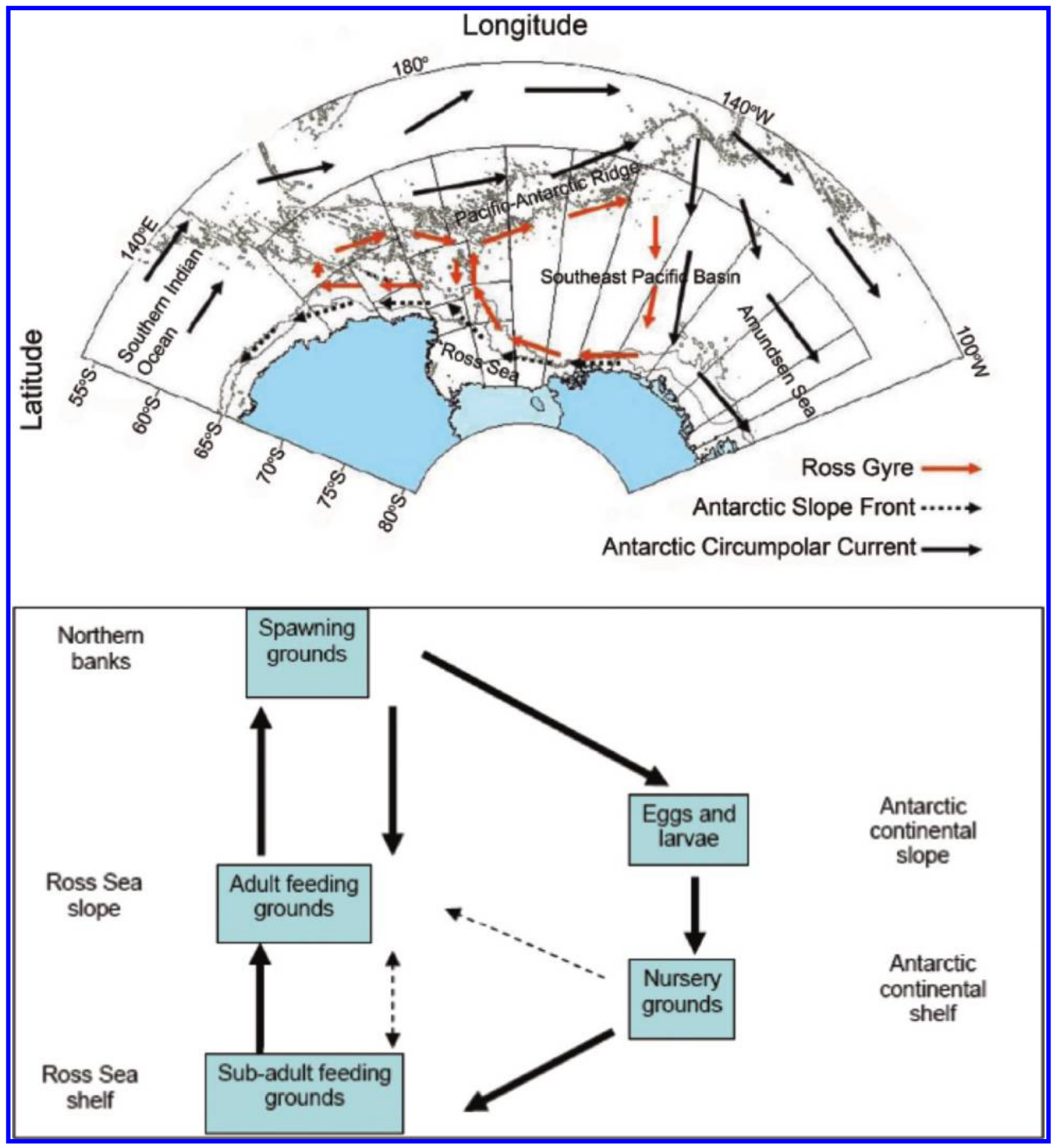

different mixtures of CDW (Ashford et al. 2010) along shelf systems off the Antarctic Peninsula and South Georgia. Fish from a single population, exposed to the same environment during early life, deposit the same chemistry in their otolith nuclei. Fish continue to carry the same nucleus chemistry, even after subsequent dispersal to different environments, providing a natural marker that can be used to link fish to their parent population. In the Antarctic, nucleus chemistry has successfully detected known population boundaries (Ashford et al. 2006; Ashford and Jones 2007) and has been used to test population hypotheses (Ashford et al. 2010) and examine population structuring by the large-scale circulation (Ashford et al. 2008).

Despite the sensitivity of otolith chemistry to environmental properties, however, fish biologists have rarely used it to test hypotheses that explicitly incorporate a hydrographic context. By contrast, particle simulations based on a circulation model, used to examine physical-biological interactions in the Southern Ocean, have successfully provided insight into the population biology of krill (e.g., Fach and Klinck 2006; Thorpe et al. 
2007). However, even though such simulations are highly spatially explicit and rigorously specified, the uncertainty involved in reproducing physical processes can undermine wider acceptance of the models' predictions. Instead, by testing these predictions empirically against distributions of otolith chemistry, the two techniques can be used to address spatially explicit hypotheses that relate connectivity to the physical circulation of oceanic systems (Ashford et al. 2010).

The combined approach has already been used to elucidate interactions between hydrography and life history that structure mixing assemblages of juvenile Patagonian toothfish (Dissostichus eleginoides) on the Patagonian Shelf (Ashford et al. 2012). Nevertheless, similar nucleus chemistry in fish spawned together limits application to questions within population. Instead, age data can be used to examine structuring in dispersing fish, the subsequent distributions of life stages and cohorts of a population between areas, and infer their relationship to transport pathways. Used together, the three techniques promise a multidisciplinary approach to address complex life history structuring and connectivity related to the physical circulation.

\section{The physical system in the Ross Sea and Southeast Pacific Basin}

Physical forcing drives transport pathways that connect areas around the Antarctic where adult and juvenile toothfish are caught and generates regional hydrographies that structure fish assemblages and the chemistry laid down in their otoliths. Thus, eastward flow in the ACC is concentrated in high-speed jets associated with fronts (e.g., Orsi et al. 1995). Its southern boundary lies above the Pacific-Antarctic Ridge in the SPB; farther downstream, the boundary and the Southern ACC Front are located close to the continental slope along the eastern Amundsen Sea, Bellingshausen Sea, and western Antarctic Peninsula (Orsi et al. 1995). Upper CDW transported in the ACC floods the shelf along the Peninsula, mixing with Winter Water to form a deep layer of Modified CDW (e.g., Smith et al. 1999) that has been successfully detected in the chemistry of fish otoliths (Ashford et al. 2010).

By contrast, in the SPB south of the ACC, near-surface flow connects along the northern and southern limbs of two cyclonic cells northwest and northeast of the Ross Sea (Locarnini 1994; Rickard et al. 2010) to form the Ross Gyre. The surface layer is occupied by Antarctic Surface Water (AASW), below which density surfaces slope upwards toward the pole, bringing warm, nutrient-rich CDW close to the surface near the ACC's southern boundary (Orsi et al. 1995). The boundary between the ACC and Ross Gyre lies above the PacificAntarctic Ridge, marked by the poleward limit of Upper CDW. The core of Lower CDW rises sharply from $2000 \mathrm{~m}$ to less than $400 \mathrm{~m}$, and strong flow along the Ridge (Locarnini 1994) splits, one branch continuing eastward in the ACC and the other southwestward in the Ross Gyre. Lower CDW forms a relatively warm, salty layer at mid-depth, which ends abruptly at the continental shelf, in the Antarctic Slope Front, where it flows westward along the southern limb of the Ross Gyre in the Antarctic Slope Current, moving cyclonically northwards and then westward from the Iselin Bank. Deeper waters follow the same cyclonic circulation but reach farther east.
In the Ross Sea, a westward current flows along the front of the Ross Ice Shelf, and inflow from the shelf break follows the west side of a series of banks oriented north-south on the shelf, with outflow on the eastern side (Fig. $2 a$ ). In the eastern Ross Sea, an inflow of AASW branches off the coastal current over the shelf near Cape Colbeck (Stover 2006; Orsi and Wiederwohl 2009). Cold shelf waters transported to the shelf break mix with Lower CDW to form dense water (Locarnini 1994), which sinks and flows along the base of the continental slope to form part of a western boundary current that continues northward past the Iselin Bank. Much of this flow enters the SPB rather than veering westward along the slope (Gordon et al. 2009), generating a potential transport pathway from the northern Ross Sea to toothfish spawning areas. In the western Ross Sea, CDW modified by mixing with AASW floods onto the shelf at the shelf break in the vicinity of troughs separating the north-south banks (e.g., Stover 2006). It meets equatorward flow of dense, cold High Salinity Shelf Water (HSSW), mixing to form Modified Shelf Water (Gordon et al. 2009). In the Glomar Challenger Trough, a portion of these waters contributes to formation of Low Salinity Antarctic Bottom Water (AABW), which sinks to form part of the deep western boundary current. Some of the rest of the CDW flows into the western Ross Sea or underneath the Ross Ice Shelf. There is also a northward boundary current along the Victoria Land coast. The most saline HSSW is formed in the western Ross Sea, and some of it flows northward to reach the shelf break at the northern end of the Drygalski Trough, where it participates in the formation of High Salinity AABW (Gordon et al. 2004; Whitworth and Orsi 2006). Driven by tidal mixing, the dense water flows in gravity currents down the slope, supplying the deep boundary current flowing westward along the continental margin. From the Joides Trough, less saline but nevertheless dense water flows into the Adare Basin (Gordon et al. 2009), where it turns cyclonically along the flank of the ocean ridge system that marks the western end of the SPB (Locarnini 1994), generating a second potential transport pathway northwards for adult toothfish to reach spawning grounds in the SPB.

As a result, physical forcing drives transport pathways that connect disparate areas in the Ross Sea, SPB, and along the Antarctic Peninsula where toothfish are found, while regional hydrographies characterized by contrasting mixtures of Upper $\mathrm{CDW}$, Lower CDW, AABW, and shelf waters generate heterogeneous environments advantageous for otolith chemistry. We used age data validated by lead-radium dating and simulated particle transport pathways using a numerical circulation model developed for the Ross Sea. Sampling fish caught in the northern Ross Sea and SPB by the commercial fishery, we conducted the first study to integrate otolith chemistry, spatial age distributions, and particle simulations in a comprehensive test of the life cycle hypothesis proposed by Hanchet et al. (2008).

\section{Materials and methods}

\section{Otolith analysis procedures}

Otoliths were collected from the Pacific-Antarctic Ridge and the northern shelf and slope of the western Ross Sea by CCAMLR observers on board the F/V American Warrior and 
Fig. 2. (a) Map of the Ross Sea, with schematic of the circulation showing main inflows and outflows. (b) Sampling areas for Antarctic toothfish in the Southeast Pacific Basin and northern Ross Sea. Dark lines show locations of benthic longlines. Areas sampled: PacificAntarctic Ridge, PR; Iselin Bank, IB; Mawson Bank, MB; Drygalski Trough, DT; Adare Basin, AB; Cape Adare, CA. (c) Circulation model bathymetry showing depth contours $(\mathrm{m})$. Red triangles are the starting points from which particles were initialized. Blue boxes and shaded area near the shelf break in the northern Ross Sea show destination areas where arriving particles were counted. The shaded area in the south represents the extent of the floating Ross Ice Shelf in the model.

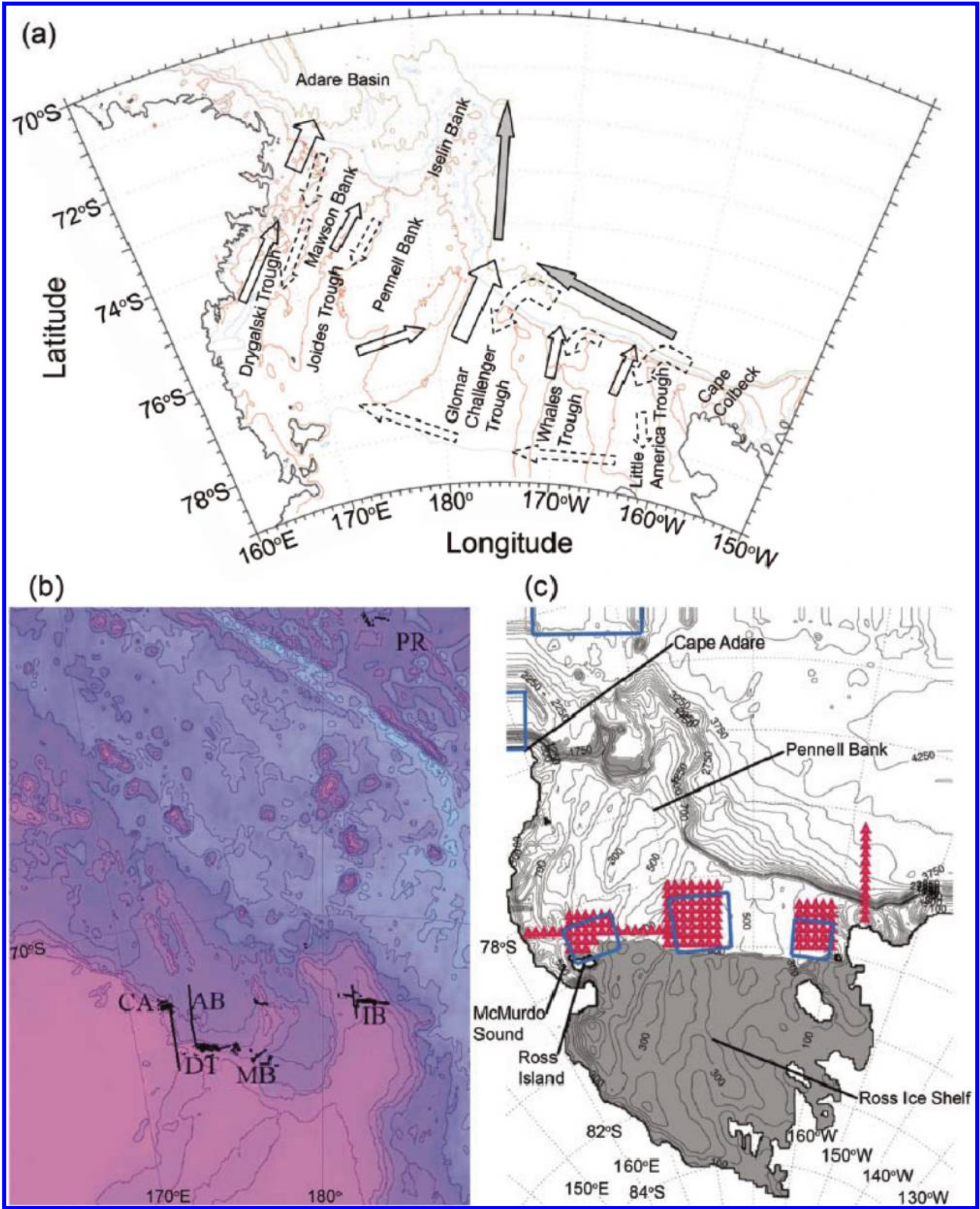


Table 1. Mean depth of capture (range), sample size (n), and mean age (standard deviation, SD) for Dissostichus mawsoni captured at sampling areas in the Southeast Pacific Basin and northern Ross Sea.

\begin{tabular}{lccrl}
\hline Area & \multicolumn{1}{l}{ Depth } & Hauls & \multicolumn{1}{l}{$n$} & \multicolumn{1}{l}{ Age } \\
\hline PR & $1742(1432-2200)$ & 19 & 77 & $17.3(3.58)$ \\
IB & $994(805-1452)$ & 55 & 560 & $14.2(3.76)$ \\
MB & $1240(698-1899)$ & 31 & 152 & $12.6(3.47)$ \\
DT & $853(502-1440)$ & 50 & 271 & $10.9(3.54)$ \\
AB & $1428(1028-1814)$ & 5 & 109 & $13.3(3.07)$ \\
CA & $1065(493-1910)$ & 23 & 243 & $9.9(3.67)$ \\
\hline
\end{tabular}

Note: Areas sampled: Pacific-Antarctic Ridge, PR; Iselin Bank, IB; Mawson Bank, MB; Drygalski Trough, DT; Adare Basin, AB; Cape Adare, CA.

F/V America I, during commercial fishing operations from March to June 2004. The observers sampled fish from the catch using a standardized protocol for randomized sampling (CCAMLR 2006) and recorded total length, mass, sex, and maturity stages. Otoliths were collected, stored dry, and transported to Old Dominion University.

One sagittal otolith was selected randomly from each pair and used for estimating age from the microstructure revealed by transverse sections as described in Brooks et al. (2011). The accuracy of the age data generated was successfully tested by a radiometric validation using the second otolith from fish randomly subsampled from the collection (Brooks et al. 2011). After validation, latitude and longitude coordinates for each haul were overlain on a habitat map in ArcGIS (Brooks 2008), and age distributions were compared between four sampling areas along the shelf slope off the Iselin Bank, Mawson Bank, Drygalski Trough, and Cape Adare, and two more from the Adare Basin and the Pacific-Antarctic Ridge (Table 1; Fig. 2b).

A second subsample was drawn, this time from fish captured within each sampling area, and the second otolith was used for otolith chemistry. To account for ontogenetic effects, 20 fish were randomly subsampled for elemental analysis from the remaining adults ( $>15$ years) from the Pacific-Antarctic Ridge, Iselin Bank, and Adare Basin. Twenty fish were also randomly subsampled from juveniles ( $<10$ years old) from the slope off the Iselin Bank, Mawson Bank, Drygalski Trough, Cape Adare, and in the Adare Basin. For external comparison, juvenile fish from the Antarctic Peninsula, which show genetic differentiation from those in the Ross Sea (Kuhn and Gaffney 2008), were selected from catches of research trawls during the 2001 United States NOAA survey of Elephant Island and the South Shetland Islands, thus providing six juvenile treatments for comparison. To remove any surface contamination, the otoliths were rinsed in Milli-Q water, placed in $20 \%$ Ultra-Pure hydrogen peroxide for $5 \mathrm{~min}$, and rinsed again in Milli-Q water. They were then ground from the anterior end using the grinding wheel of a HillQuist Thin Section machine to give a transverse surface anterior of the nucleus. Otoliths were mounted on this surface using crystal bond, which had been previously tested to ensure it was not a source of contamination, and ground from the posterior side to reveal a transverse plane through the otolith nucleus. The surface of the mounted thick section was fine-ground and polished using a
Crystalmaster 8 Machine with 30M and 3M Mark V Laboratory lapping film. In a clean room, the sections were rinsed in Milli-Q water under a laminar flow hood and lapped manually using clean plastic clamps and Mark V Laboratory polishing film. Each otolith was lapped successively on three pieces of clean $3 \mathrm{M}$ film, finished on $0.3 \mathrm{M}$ film, rinsed, and the surface soaked with $20 \%$ Ultra-Pure hydrogen peroxide for $5 \mathrm{~min}$ before rinsing again. After drying, sections from each treatment were randomly selected, removed from the slide, and mounted in random order on clean petrographic slides under a laminar-flow hood using silicon glue, also previously tested to ensure it was not a source of contamination. The mounted sections were rinsed, sonicated for $5 \mathrm{~min}$, then rinsed again, all in Milli-Q water, and left to dry.

To measure trace and minor element concentrations, we used a Finnigan MAT Element2 double-focusing sector-field inductively coupled plasma - mass spectrometer (ICP-MS) located at the Plasma Mass Spectrometry Facility at Woods Hole Oceanographic Institution (Woods Hole, Massachusetts). Samples were introduced in automated sequence (Chen et al. 2000) using laser ablation and a PFA microflow nebulizer (50 $\mu \mathrm{L} \cdot \mathrm{min}^{-1}$, Elemental Scientific Inc., Omaha, Nebraska). Ablated material from the sample cell was mixed in the spray chamber with aerosol of $1 \% \mathrm{HNO}_{3}$ introduced by the nebulizer, and the mixture was then carried to the ICP torch. Blanks of $1 \% \mathrm{HNO}_{3}$ aerosol were also introduced to the chamber by the nebulizer; for quality control, we used dissolved reference material obtained from the National Resource Council of Canada. To control for operational variability in the laser ICP-MS, a randomized blocks design was used with each petrographic slide as the blocking factor, considered randomly drawn, with otoliths selected randomly from each treatment and placed in random order on the slide. Blank and reference readings of count rate (counts. $\mathrm{s}^{-1}$ ) were obtained before and after presentation of the otolith sections in each block and for every three otoliths within a block.

Otoliths were analysed for ${ }^{48} \mathrm{Ca},{ }^{25} \mathrm{Mg},{ }^{55} \mathrm{Mn},{ }^{88} \mathrm{Sr}$, and ${ }^{138} \mathrm{Ba}$ and reported as ratios to ${ }^{48} \mathrm{Ca}$. To calculate element: $\mathrm{Ca}$ $\left(\mathrm{Me} \cdot \mathrm{Ca}^{-1}\right)$ ratios, background counts were subtracted from otolith counts by interpolating between blank readings, and the corrected otolith counts were converted to $\mathrm{Me} \cdot \mathrm{Ca}^{-1}$ concentrations using the reference readings. To determine empirically how otolith chemistry varies spatially, we sampled material laid down in the interval prior to capture by placing a line raster type along the proximo-dorsal edge of the otolith to sample the outer annulus. We used a laser beam of diameter $25 \mu \mathrm{m}$, frequency at $10 \mathrm{~Hz}$, and power at $60 \%$, travelling $\sim 900 \mu \mathrm{m}$ along the edge at $6 \mu \mathrm{m} \cdot \mathrm{s}^{-1}$ and giving a predicted mean crater width of $17 \mu \mathrm{m}$ and crater depth of approximately $100 \mu \mathrm{m}$ (Jones and Chen 2003, their eq. 3). To test for population heterogeneity, we sampled material laid down during early life. We placed a grid raster type $150 \mu \mathrm{m} \times 200 \mu \mathrm{m}$ within the nucleus and used the same settings to sample material laid down during the first year of life (La Mesa 2007), including the primordium and material surrounding the primordium.

\section{Statistical methods}

For edge and nucleus data, multivariate outliers were identified in separate analyses for adult and juvenile toothfish by 
plotting robust squared Mahalanobis distances of the residuals $\left(D_{i}^{2}\right)$ against the corresponding quantiles (QQ plot) of the $\chi^{2}$ distribution (Khattree and Naik 1999). Based on tests using Mardia's multivariate skewness and kurtosis measures $(\alpha=$ $0.05)$ and QQ plots of squared Mahalanobis distances $\left(d_{i}^{2}\right)$, neither edge nor nucleus data conformed to multivariate normality; variance-covariance matrices were not equal according to Bartlett's modification $(\alpha=0.1)$. However, univariate power transformations (e.g., Kuehl 1994 p. 121; Ashford et al. 2007) stabilized the variances ( $F_{\max }$ test, $t=4, v=19, \alpha=$ 0.01 ); the transformed data conformed to multivariate normality with equal variance-covariance matrices. The data transformations selected for the adult edge data were $y^{0.2}$ for $\mathrm{Mg} \cdot \mathrm{Ca}^{-1}, y^{-0.3}$ for $\mathrm{Sr} \cdot \mathrm{Ca}^{-1}, y^{-0.4}$ for $\mathrm{Ba} \cdot \mathrm{Ca}^{-1}$; for the juvenile edge data, the data transformations were $y^{0.1}$ for $\mathrm{Mg} \cdot \mathrm{Ca}^{-1}, y^{0.6}$ for $\mathrm{Sr} \cdot \mathrm{Ca}^{-1}, \log (y)$ for $\mathrm{Ba} \cdot \mathrm{Ca}^{-1}$. For the nucleus data, the transformations were the same for adults and juveniles: $y^{-0.4}$ for $\mathrm{Mg} \cdot \mathrm{Ca}^{-1}, y^{-1}$ for $\mathrm{Sr} \cdot \mathrm{Ca}^{-1}$, and $y^{-0.6}$ for $\mathrm{Ba} \cdot \mathrm{Ca}^{-1}$.

Since these data satisfied assumptions, we used multivariate analysis of variance (ANOVA) to test (i) the edge data for environmental heterogeneity along the northern slope of the Ross Sea and between the slope and SPB and (ii) the nucleus data for population heterogeneity that would indicate more than one population. For the adults, we constructed contrasts among the Pacific-Antarctic Ridge, the Iselin Bank, and Adare Basin; for juveniles, contrasts were among the Iselin Bank, northern slope of the Ross Sea, Adare Basin, and the Antarctic Peninsula. We used univariate models to examine the influence of each $\mathrm{Me} \cdot \mathrm{Ca}^{-1}$ ratio; since $\mathrm{Mn} \cdot \mathrm{Ca}^{-1}$ values were less than detection limits and showed no differences, they were not included in the analyses. Since variance-covariance ratios were equal for all four analyses, we calculated canonical discriminant variates to illustrate graphically the environmental and population heterogeneity between areas (Khattree and Naik 2000). Because our interest did not lie in allocating samples of unknown provenance to areas or populations represented in a training set, we did not use discriminant analysis to examine classification success.

Age data were mapped in space according to corresponding latitudinal and longitudinal haul data and then grouped according to the distinct regions where hauls were aggregated. We then used a one-way ANOVA ( $\alpha=0.05)$ to test for structuring between sampling areas consistent with connectivity along (i) the eastern pathway northward from the Iselin Bank and (ii) the western pathway into the Adare Basin. Data fulfilled the assumption of equality of variances (Levene's test, $p=$ $0.64)$ without transformation; there was some evidence of kurtosis and skewness (Kolmogorov-Smirnov, $\alpha=0.05$ ), but ANOVA is generally robust to moderate departures from normality. To evaluate differences between areas, we used Duncan's multiple range test, which is a variant of the Student-Newman-Keuls test for pairwise comparisons in an ordered array of all treatment means based on experimentwise error rates.

\section{Lagrangian particle tracking}

We further examined potential transport pathways by releasing particles in the large-scale circulation simulated by a numerical circulation model, which is based on a highresolution version of the Regional Ocean Modeling System (ROMS; Shchepetkin and McWilliams 2005; Haidvogel et al.
2008; Shchepetkin and McWilliams 2009) that was configured for the Ross Sea (Dinniman et al. 2003; 2011). The ROMS implementation for the Ross Sea is a three-dimensional ocean primitive equation finite difference model that uses a terrainfollowing vertical coordinate system as described in Dinniman et al. (2011). The model domain (Fig. 2c) extends from north $\left(67.5^{\circ} \mathrm{S}\right)$ of the continental shelf break southward to $85^{\circ} \mathrm{S}$, including almost all of the cavity beneath the Ross Ice Shelf and parts of the southern and western limbs of the Ross Gyre. The horizontal grid spacing is $5 \mathrm{~km}$, and the vertical resolution is determined by 24 vertical levels, the thickness of which varies with the water column depth, but are concentrated towards the top and bottom surfaces. The model simulates the thermodynamic and mechanical forcing of the floating ice shelf on the water in the cavity beneath. In place of a fully dynamic sea ice model, ice concentrations from satellite observations are imposed, and ice melt or freeze is calculated from the imposed ice distribution. The model surface heat flux is calculated as a linear combination of heat flux due to ice cover and the open-water heat flux, with the ratio determined by the ice concentration in a particular grid cell. The daily winds used to force the ocean are taken from forecasts from the Antarctic Mesoscale Prediction System (AMPS; Powers et al. 2003; Bromwich et al. 2005), which uses a mesoscale meteorological model to compute high-resolution atmospheric forecast fields for Antarctica. The AMPS model grid provided winds at $30 \mathrm{~km}$ horizontal spacing over much of the Southern Ocean (including our entire model domain). Model simulations are forced by daily winds representing the period $15 \mathrm{Sep}-$ tember 2001 - 15 September 2003. Ocean tides are not included in this model.

The ocean circulation model provided current fields $(u$ and $v$ components of the flow) that were used to estimate the trajectory followed by a particle $(\vec{X})$ in space $(x, y, z)$ and time $(t)$, as

$$
\frac{\mathrm{d} \vec{X}}{\mathrm{~d} t}=\vec{U}(\vec{X}, t)+W_{v w} \widehat{Z}
$$

where $\frac{d \vec{X}}{d t}$ is the change of the location of the particle in the three-dimensional field with time. The location is modified by the advective velocity field $(\vec{U}(\vec{X}, t))$, obtained from the circulation model, and vertical diffusivity, which was included by adding a vertical random walk to the particle location. The random vertical displacement $\left(W_{v w}\right)$ was added to the vertical $(\widehat{Z})$ particle location at each time step (Hunter et al. 1993; Visser 1997).

The numerical integration for the Lagrangian circulation was done using a fourth-order Milne predictor (Abramowitz and Stegun 1964) and a fourth-order Hamming corrector scheme (Hamming 1973). A forward difference scheme was used when vertical displacement resulting from vertical walk parameterization was estimated. The vertical displacement has a Gaussian probability distribution with a correction for the vertical gradient in the diffusion coefficient. A 4 min integration time was used for the Lagrangian particles, and the location of each particle was obtained at $30 \mathrm{~min}$ intervals.

Particles were initialized in four locations: $(i)$ an eastern set initialized in the surface layer and at depths of 100, 300, 500, and $1000 \mathrm{~m}$ across the continental slope (Fig. 2c); (ii) an 
eastern set initialized in the bottom layer of the Little America Trough; (iii) a central set initialized in the bottom layer in the Glomar Challenger Trough; and (iv) a western set initialized in the bottom layer and at depths of 100 and $400 \mathrm{~m}$ in the southwestern Ross Sea, including the southern Drygalski Trough. Releases across the continental slope were used to examine subsequent trajectories from the southern limb of the Ross Gyre; particles in the surface layer corresponded to the part of the water column considered occupied by young toothfish stages, and those at 500 and $1000 \mathrm{~m}$ corresponded to the depths occupied by adults caught in the fishery. The release locations over the shelf corresponded to areas where juvenile fish are caught in the fishery (Hanchet et al. 2008; Hanchet 2010). A full set of particles was released into the simulated circulation fields from all locations once a month, and every particle was tracked for 400 days or until it exited the model domain. The number of Lagrangian particles arriving at six destination boxes in the eastern, central, and western Ross Sea, along the northern shelf break, along the western model boundary across the continental slope, and along the northern model boundary in the SPB were used to assess the dominant transport pathways.

\section{Results}

\section{Otolith chemistry}

Examining the chemistry along the otolith edges for environmental heterogeneity between sampling areas, we found significant differences in adults (multivariate ANOVA Pillai's trace; $F=25.2$; df $=6 ; p<0.0001$ ) and juveniles (Pillai's trace; $F=12.33$; df $=15 ; p<0.0001$; Fig. 3 ). In adults, significant differences in the contrast between the PacificAntarctic Ridge and Iselin Bank (multivariate ANOVA Pillai's trace; $F=15.3$; df $=3 ; p<0.0001$ ) indicated strong environmental structuring; significant differences between the Pacific-Antarctic Ridge and Adare Basin (Pillai's trace; $F=$ $15.3 ; \mathrm{df}=3 ; p<0.0001$ ) indicated environmental heterogeneity along the ocean ridge system at the western end of the SPB. Moreover, significant differences between the Iselin Bank and Adare Basin (Pillai's trace; $F=34.8$; df $=3 ; p<$ 0.0001 ) indicated otolith chemistry recorded differential environmental exposures for each putative transport pathway. In the juveniles, the otolith edges showed significant differences from the Iselin Bank to the sampling areas farther west along the continental slope (Pillai's trace; $F=13.2$; $\mathrm{df}=3 ; p<$ 0.0001). Samples from Iselin Bank and along the slope were significantly different from the Adare Basin (Pillai's trace; $F=4.61 ; \mathrm{df}=3 ; p<0.0045$ ). Juvenile fish from the Antarctic Peninsula showed edge chemistry that was significantly different from all other fish sampled (Pillai's trace; $F=$ 74.54; $\mathrm{df}=3 ; p<0.0001$ ), indicating strong structuring in environmental exposures between the Ross Sea and the Antarctic Peninsula.

Nevertheless, despite the heterogeneity demonstrated in the edge chemistry, the nucleus chemistry showed no differences among adult toothfish taken on the Pacific-Antarctic Ridge, Iselin Bank, and Adare Basin (MANOVA Pillai's trace; $F=$ 1.78; $\mathrm{df}=6 ; p>0.05$ ); or between juveniles taken in the Ross Sea and Adare Basin (Pillai's trace; $F=1.64 ; \mathrm{df}=12 ; p>$ 0.05 ; Fig. 4). Only when the nucleus chemistry from fish taken in research trawls off the Antarctic Peninsula was included in the analysis for juveniles did we find any spatial differences
(Pillai's trace; $F=2.49 ; \mathrm{df}=15 ; p=0.0017$ ), with a significant contrast between the Antarctic Peninsula and Ross Sea (Pillai's trace; $F=6.84$; $\mathrm{df}=3 ; p=0.0003$ ).

Examining the univariate data for adults, the otolith edges showed environmental heterogeneity that was significant (Table 2), with differences between the transformed means for the Pacific-Antarctic Ridge and Adare Basin reaching 1.2 standard deviations (SD) for $\mathrm{Mg} \cdot \mathrm{Ca}^{-1}, 3.0 \mathrm{SD}$ for $\mathrm{Sr} \cdot \mathrm{Ca}^{-1}$, and 2.5 SD for $\mathrm{Ba} \cdot \mathrm{Ca}^{-1}$. Yet none of the three ratios showed significant differences for the nucleus chemistry (Table 3). For juveniles, differences in the edge chemistry reached nearly 1.5 SD for $\mathrm{Mg} \cdot \mathrm{Ca}^{-1}, 4.0 \mathrm{SD}$ for $\mathrm{Sr} \cdot \mathrm{Ca}^{-1}$, and 3.3 SD for $\mathrm{Ba} \cdot \mathrm{Ca}^{-1}$, larger than that for the adults. Additionally, differences in the nucleus chemistry of juveniles between the Antarctic Peninsula and the other sampling areas were significant for all three element ratios. Yet we did not find evidence of population heterogeneity in any of the three element ratios in the juveniles from the northern Ross Sea and Adare Basin.

\section{Age distributions}

Examining age distributions for spatial structuring corresponding to the two putative transport pathways, ANOVA showed significant differences between sampling areas (Table 4). Consistent with adult migration northwards along the eastern pathway, all fish sampled on the Pacific-Antarctic Ridge were aged 11 years or more, with a large proportion older than 16 years (Fig. 5); fish on the Iselin Bank comprised a similar age range, but with a mode at 13 years and a smaller proportion of fish older than 16 years. A small proportion of juvenile fish appeared to follow a separate distribution; these were less than 10 years old, younger than the age at which immature fish reach neutral buoyancy.

Examining the western transport pathway into the Adare Basin, the age distributions north of the Mawson Bank and in the Adare Basin were significantly different from the Iselin Bank but not from each other, consistent with downslope connectivity. Evidence of bimodality was particularly strong north of the Mawson Bank, with a higher proportion of fish less than 10 years showing a mode at 7 years, and the lack of structuring indicated connectivity down the slope affected juveniles as well as adults.

In contrast, the age distributions of fish off the Drygalski Trough and Cape Adare were both significantly different, with increasing proportions of younger fish. There were few fish older than 16 years off Cape Adare, west of the zone of AABW formation, and significant differences from the Mawson Bank and Adare Basin indicated that even if fish are also transported to depth by gravity flows from the Drygalski Trough, they do not enter the Adare Basin.

\section{Lagrangian particle tracking}

The original simulations by Hanchet et al. (2008) suggested a large proportion of toothfish early life stages are transported from the Pacific-Antarctic Ridge along the Ross Gyre towards the eastern Ross Sea. Simulations of subsequent transport using ROMS showed that a large number of the drifters released in the surface layer across the continental slope of the eastern Ross Sea followed trajectories along the shelf break corresponding to the Antarctic Slope Front (Fig. 6). Some of these entered the eastern Ross Sea via the Whales and Little America troughs, but a larger number crossed into the western 
Fig. 3. Chemistry from otolith edges of Dissostichus mawsoni. (a) Mean concentrations of $\mathrm{Mg} \cdot \mathrm{Ca}^{-1}, \mathrm{Sr} \cdot \mathrm{Ca}^{-1}$, and $\mathrm{Ba} \cdot \mathrm{Ca}^{-1}$ for adults (left panels) and juveniles (right panels) caught on Pacific-Antarctic Ridge (PR); Iselin Bank (IB); shelf break off Mawson Bank (MB), Drygalski Trough (DT), and Cape Adare (CA); Adare Basin (AB); and Antarctic Peninsula (AP). Bars show standard error. (b) Relationships using canonical

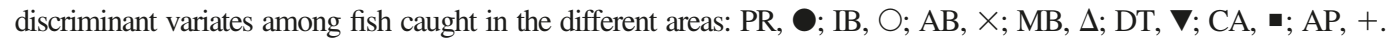

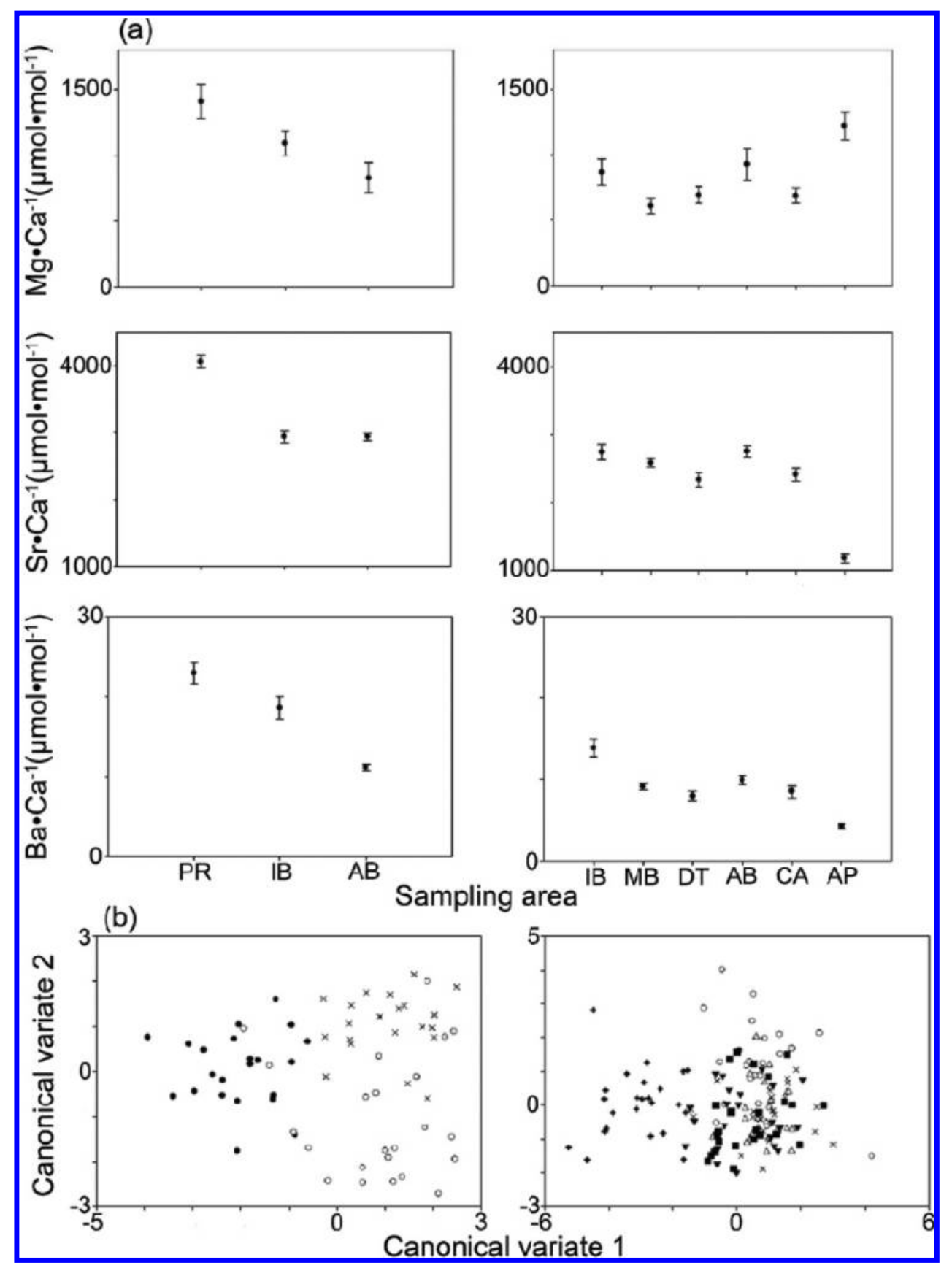

Ross Sea at the point of maximum curvature in the shelf break. The shelf circulation then took them along the Glomar Challenger Trough. In contrast, particles initialized from the same location, but farther offshore, were transported in the western boundary current past the Iselin Bank. Overall, a high proportion of surface particles released across the continental slope reached, at some point during their trajectory, areas where juveniles have been caught in the fishery: $15 \%$ in the western Ross Sea, $28 \%$ in the central Ross Sea, and $20 \%$ in the shelf break along the northern Ross Sea (Table 5).
With increasing depth, the proportions of particles reaching these juvenile areas declined. At $300 \mathrm{~m}$, only $8 \%$ of particles reached the western Ross Sea grounds and only $10 \%$ reached the central Ross Sea. In deeper water, where adult toothfish are predominantly caught by the fishery, most particles either followed the western boundary current, passing north towards the Pacific-Antarctic Ridge directly along the eastern side of the Iselin Bank, or followed the flow around the bank and into the Adare Basin, consistent with adult age distributions. A few particles also passed along the Joides Trough. Fewer particles 
Fig. 4. Chemistry from otolith nuclei of Dissostichus mawsoni. (a) Mean concentrations of $\mathrm{Mg} \mathrm{Ca}^{-1}, \mathrm{Sr} \cdot \mathrm{Ca}^{-1}$, and $\mathrm{Ba}^{-\mathrm{Ca}}{ }^{-1}$ for adults (left panels) and juveniles (right panels) caught on the Pacific-Antarctic Ridge (PR); Iselin Bank (IB); shelf break off Mawson Bank (MB), Drygalski Trough (DT), and Cape Adare (CA); Adare Basin (AB); and Antarctic Peninsula (AP). Bars show standard error.

(b) Relationships using canonical discriminant variates among fish caught in the different areas: PR, 0 ; IB, $\bigcirc$; AB, $\times$; MB, $\Delta$; DT, $\mathbf{\nabla}$; $\mathrm{CA},-\mathrm{AP},+$.

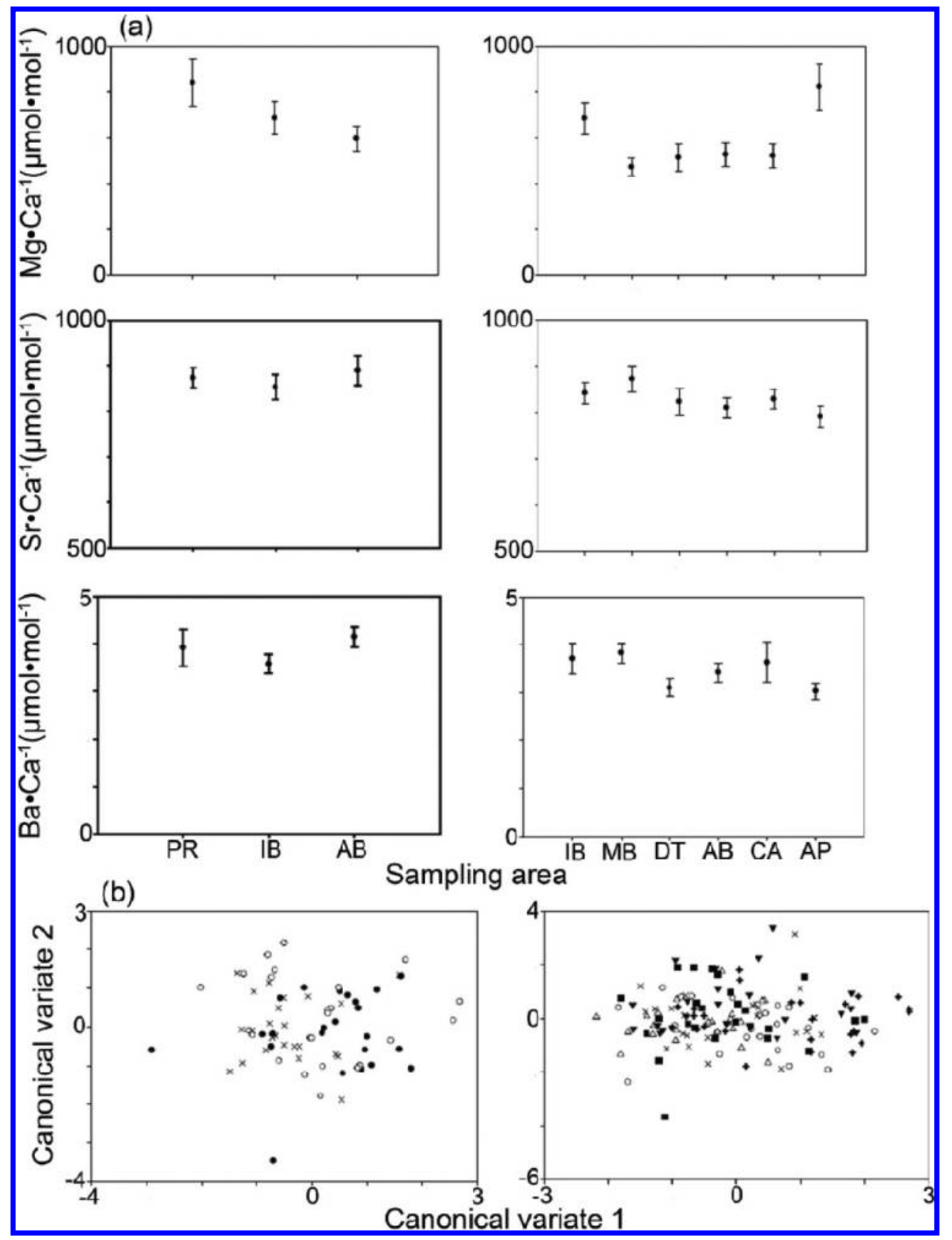

reached the western, central, and eastern Ross Sea, but the number reaching the continental slope in the northern Ross Sea increased from $15 \%$ at $300 \mathrm{~m}$ to $22 \%$ at $500 \mathrm{~m}$. Similar proportions reached the model boundary in the northern SPB ( $24 \%$ at $1000 \mathrm{~m})$, moving towards the Pacific-Antarctic Ridge. Twenty-two per cent released at $500 \mathrm{~m}$ reached the western boundary, reflecting westward flow along the continental shelf and slope. The importance of flow to the PacificAntarctic Ridge relative to flow westward, reflected in the ratio of particles reaching the northern and western boundaries, increased with depth from 1 at $500 \mathrm{~m}$ to 1.5 at $1000 \mathrm{~m}$.

Particles released from the seafloor in juvenile areas in the southwestern Ross Sea (Fig. 6) were largely transported northwards along the Drygalski Trough to reach the northern shelf break where they joined the westward flow along the Antarctic Slope Front. Of those released, 39\% reached the continental slope in the northern Ross Sea, whereas only $10 \%$ were transported to the central Ross Sea and none to the eastern 
Table 2. Mean square estimates for edge chemistry from randomized block analysis of variance (ANOVA), testing for differences in concentrations of $\mathrm{Mg} \cdot \mathrm{Ca}^{-1}, \mathrm{Sr} \cdot \mathrm{Ca}^{-1}$, and $\mathrm{Ba} \cdot \mathrm{Ca}^{-1}$ in (i) adults sampled from the Pacific-Antarctic Ridge, Iselin Bank, and Adare Basin and (ii) juveniles sampled from the shelf slope off Iselin Bank, Mawson Bank, Drygalski Trough, and Cape Adare; in the Adare Basin; and along the Antarctic Peninsula.

\begin{tabular}{lrlcl}
\hline & df & $\mathrm{Mg} \cdot \mathrm{Ca}^{-1}$ & $\mathrm{Sr} \cdot \mathrm{Ca}^{-1}$ & $\mathrm{Ba} \cdot \mathrm{Ca}^{-1}$ \\
\hline Adults & & & & \\
Slide (block) & 23 & $0.225^{*}$ & 0.00001 & 0.0015 \\
Sampling area & 2 & $1.221 * * *$ & $0.00052^{* * *}$ & $0.0522^{* * *}$ \\
Residual & 41 & 0.110 & 0.00001 & 0.0014
\end{tabular}

\section{Juveniles}

\begin{tabular}{lrlcl} 
Slide (block) & 23 & 0.0093 & 156 & 0.127 \\
Sampling area & 5 & $0.0566^{* * *}$ & $7462^{* * *}$ & $3.514 * * *$ \\
Residual & 113 & 0.0092 & 148 & 0.131 \\
\hline
\end{tabular}

Note: ${ }^{*}, p<0.05 ;{ }^{* *}, p<0.01$; ***, $p<0.001$.

Table 3. Mean square estimates for nucleus chemistry from randomized block analysis of variance (ANOVA), testing for differences in concentrations of $\mathrm{Mg} \cdot \mathrm{Ca}^{-1}, \mathrm{Sr} \cdot \mathrm{Ca}^{-1}$, and $\mathrm{Ba} \cdot \mathrm{Ca}^{-1}$ in (i) adults sampled from the Pacific-Antarctic Ridge, Iselin Bank, and Adare Basin and (ii) juveniles sampled from the shelf slope off Iselin Bank, Mawson Bank, Drygalski Trough, and Cape Adare; in the Adare Basin; and along the Antarctic Peninsula.

\begin{tabular}{lrlll}
\hline & df & $\mathrm{Mg} \cdot \mathrm{Ca}^{-1}$ & $\mathrm{Sr} \cdot \mathrm{Ca}^{-1}$ & $\mathrm{Ba} \cdot \mathrm{Ca}^{-1}$ \\
\hline Adults & & & & \\
Slide (block) & 23 & 0.00022 & $3.1 \times 10^{-8}$ & 0.0064 \\
Sampling area & 2 & 0.00046 & $1.1 \times 10^{-8}$ & 0.0126 \\
Residual & 45 & 0.00018 & $3.2 \times 10^{-8}$ & 0.0055 \\
& & & & \\
Juveniles & & & & \\
Slide (block) & 23 & 0.00019 & $4.97 \times 10^{-8 * *}$ & $0.0127^{*}$ \\
Sampling area & 5 & $0.00079 * *$ & $3.63 \times 10^{-8}$ & $0.0183^{*}$ \\
Residual & 113 & 0.00024 & $3.73 \times 10^{-8}$ & 0.0059 \\
\hline
\end{tabular}

Note: $*, p<0.05$; **, $p<0.01$; ***, $p<0.001$.

Ross Sea. Moreover, $48 \%$ reached the western model boundary along the continental slope compared with only $2 \%$ reaching the northern boundary. This pattern remained true throughout the water column, indicating that fish off the Drygalski Trough and Cape Adare are unlikely to be transported into the Adare Basin, consistent with the age data. Large proportions of particles released from both the Glomar Challenger Basin and the eastern Ross Sea also reached the northern Ross Sea (23\% and 33\%, respectively) and the western boundary (27\% and $32 \%$, respectively). However, in contrast with the Drygalski Basin, $31 \%$ of the particles from the Glomar Challenger Basin and 16\% from the eastern Ross Sea reached the northern boundary. Nearly half of the particles released from the eastern Ross Sea also passed through the Glomar Challenger Trough, whereas none passed in the reverse direction.

These results predict that early life stage toothfish travelling from the Pacific-Antarctic Ridge and following the flow in the
Table 4. (a) Mean square estimates from one-way analysis of variance (ANOVA) and (b) ordered array from Duncan's multiple range test.

(a) Mean square estimates from ANOVA.

\begin{tabular}{lrc}
\hline & df & Mean square \\
\hline Sampling area & 5 & $1148^{* * *}$ \\
Residual & 1435 & 13
\end{tabular}

(b) ordered array from Duncan's multiple range test.

\begin{tabular}{llllll}
\hline PR & $\overline{\mathrm{IB}}$ & $\overline{\mathrm{AB}}$ & $\mathrm{MB}$ & $\overline{\mathrm{DT}}$ & $\overline{\mathrm{CA}}$
\end{tabular}

Note: (a) Mean square estimates test for differences in age distributions between toothfish sampled. (b) Significant differences are indicated by line gaps between areas for the ordered array from Duncan's multiple range test. PR, Pacific-Antarctic Ridge; IB, Iselin Bank; AB, Adare Basin; MB, Mawson Bank; DT, Drygalski Trough; CA, Cape Adare. $* * *, p<0.001$.

Ross Gyre are unlikely to recruit only to the eastern Ross Sea, but would also be advected to juvenile areas in the western Ross Sea. A large proportion of adults feeding in pelagic waters following spawning, on the other hand, would be transported in the Ross Gyre towards the Amundsen Sea and then along the shelf slope from the eastern Ross Sea to the Iselin Bank and thence back to the Pacific-Antarctic Ridge. Taken with the evidence from the age distributions and otolith chemistry, this suggests a single, self-recruiting population with a life history structured by the large-scale circulation in the Ross Gyre and Ross Sea.

\section{Discussion}

\section{A single Ross Sea population explains the data}

Testing the life cycle proposed by Hanchet et al. (2008), we were unable to refute (Popper 1959) the hypothesis of a single population of toothfish with connectivity between the Ross Sea and SPB. The nucleus chemistry of adult and juvenile Antarctic toothfish showed no differences among the PacificAntarctic Ridge, northern Ross Sea, and Adare Basin, indicating that fish caught in the Ross Sea and SPB fishery all recruited from the same spawning area. Age data, too, were consistent with adult connectivity between the northern Ross Sea and SPB. Fish in catch taken on the Pacific-Antarctic Ridge were all older than the ontogenetic threshold from negative to neutral buoyancy. Catch on the Iselin Bank contained large concentrations of adults, and the proportion decreased westward along the Antarctic Slope Current. Moreover, the age distribution of fish in the Adare Basin was similar to that of fish off the Mawson Bank, consistent with connectivity via rapid tidal sinking of benthic waters associated with AABW formation. The particle simulations indicated that up to a quarter of the simulated drifters were advected northwards into the SPB relying solely on passive transport, without invoking active migration. Taken together, the three techniques indicated a single population with adult movement along two deep pathways, northward from the Iselin Bank and Adare Basin towards the Pacific-Antarctic Ridge.

The lack of differentiation in the nucleus chemistry could not be explained by similar environmental conditions between 
Fig. 5. Age structure of Dissostichus mawsoni caught by commercial benthic longliners between March and June 2004 off the PacificAntarctic Ridge (PR); Iselin Bank (IB); the shelf break off Mawson Bank (MB), Drygalski Trough (DT), and Cape Adare (CA); and in the Adare Basin $(\mathrm{AB})$.

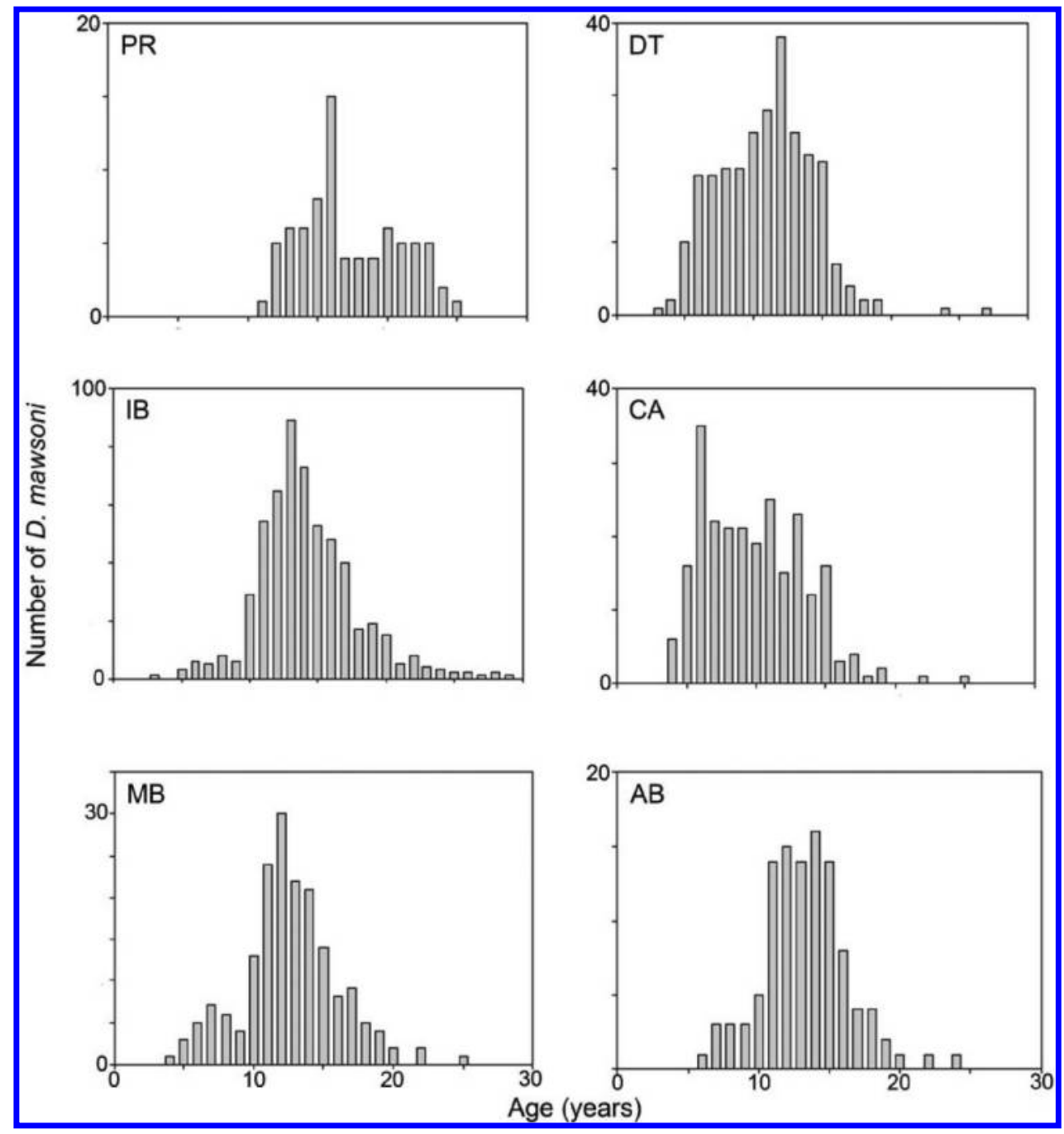

areas, which can prevent the technique from identifying spatially segregated origins. Evidence from the edge chemistry demonstrated some of the strongest spatial differentiation yet observed, much larger than measured off the Patagonian Shelf and north Scotia Ridge (up to 2.6 SD; Ashford et al. 2007) and in shelf waters over the Patagonian Shelf (between 1.0 and 1.9 SD; Ashford et al. 2012), and comparable with differences in stable isotope concentrations in fish exposed to Antarctic Intermediate Water and CDW (2.5-3.75 SD; Ashford and Jones 2007). The differences were configured along the spatial axes of most interest: between the Pacific-Antarctic Ridge and northern Ross Sea and along the northern Ross Sea shelf. The strength and configuration of these differences suggested that the chemistry reflected exposure to Lower CDW, and shelf water mixing in the production of $\mathrm{AABW}$ associated with the Joides and Drygalski troughs. Thus, $\mathrm{Sr} \cdot \mathrm{Ca}^{-1}$, indicative of CDW in previous studies (Ashford et al. 2005, 2007), was much higher in the area occupied by Lower CDW on the Pacific-Antarctic Ridge than in the northern Ross Sea, whereas $\mathrm{Ba} \cdot \mathrm{Ca}^{-1}$, associated with oceanic waters in previous studies, was also highest on the Pacific-Antarctic Ridge and showed a decrease in concentration west of the Iselin Bank. Even edge $\mathrm{Mg} \cdot \mathrm{Ca}^{-1}$, which reflects changes in physiology associated with reproduction and movement, showed high concentrations on the Pacific-Antarctic Ridge and, like $\mathrm{Ba} \cdot \mathrm{Ca}^{-1}$, decreased west of the Iselin Bank.

Neither was the lack of spatial differences in the nucleus chemistry due to a lack of statistical power. We used a sample size of $n=20$, yet a sample size of only $n=16$ per treatment was required to detect much smaller differences of only a single SD with a power of $1-\beta=0.8$. Adequate statistical power was by definition confirmed by successful corroboration of population structuring between the Ross Sea and Antarctic Peninsula already demonstrated by genetic approaches (Kuhn and Gaffney 2008). Moreover, the genetics also suggested a single population in the Ross Sea, with no differentiation between northern and southern areas, consistent with Hanchet et al.'s (2008) hypothesis.

Resolving power was not an issue for the age data because differences were found between most samples. Validation of the data set using radiometry showed no significant biases and no evidence of unacceptable reader error (Brooks et al. 2011). 
Fig. 6. Simulations of particle trajectories originating from (a) arrays across the eastern continental shelf, released at the surface (blue), $100 \mathrm{~m}$ (black), and $300 \mathrm{~m}$ (yellow), and in the southern Drygalski Basin, released in the bottom layer (red), and (b) arrays across the eastern continental shelf, released at $500 \mathrm{~m}$ (black) and $1000 \mathrm{~m}$ (yellow), and in the eastern Ross Sea (blue) and Glomar Challenger Basin (red), released in the bottom layer.

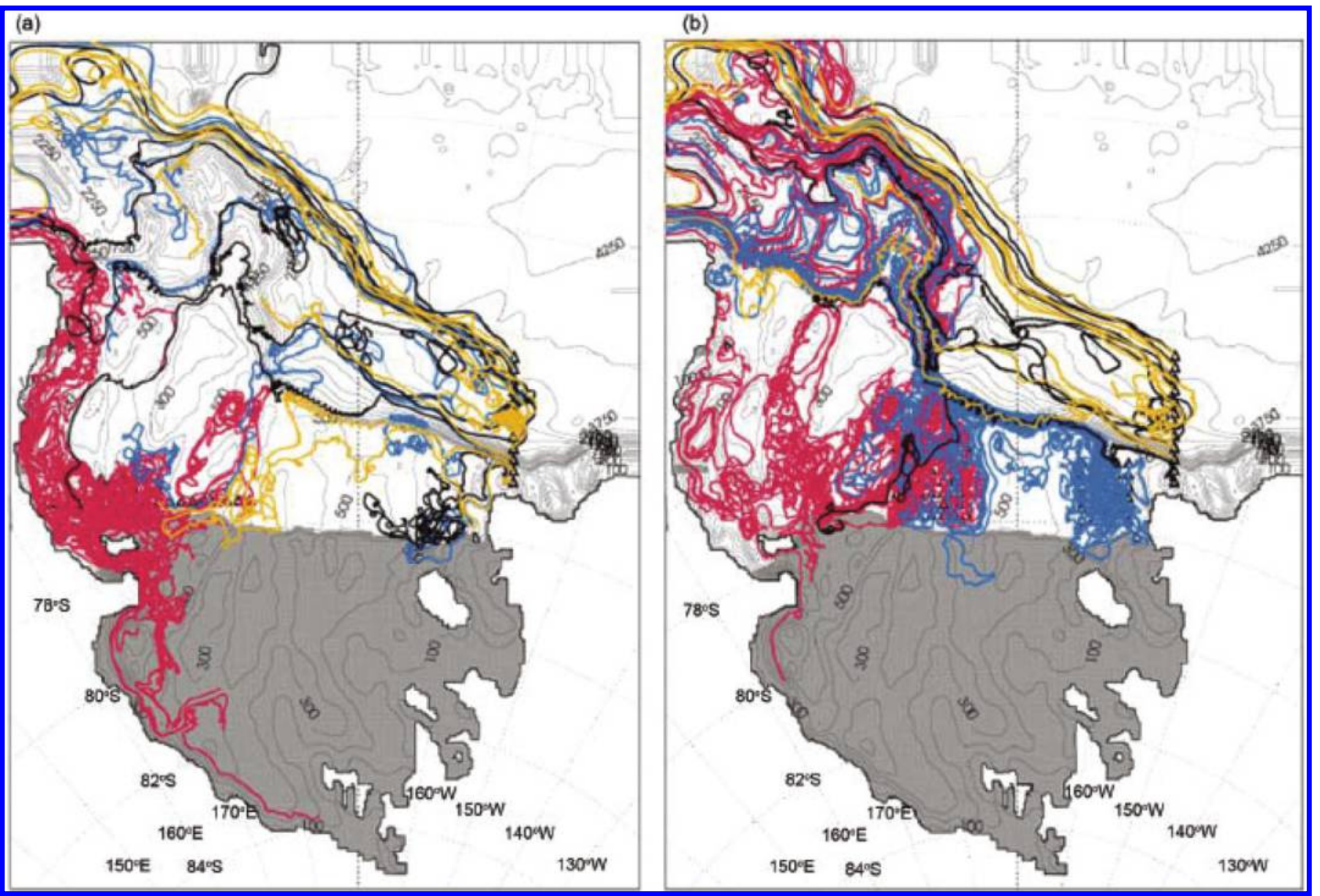

The age distributions corroborated the resolution, showing clear juvenile and adult modes with very little evidence of smearing between them. Nor did the lack of tidal forcing or active migration in the circulation model undermine our results. Although the omission of tidal forcing may cause an underestimate of benthic transport down the continental slope off the Joides and Drygalski troughs (e.g., Padman et al. 2009), this would in turn lead to downward bias in estimates of transport northwards from the Adare Basin. Similarly, directed behaviour would act to increase the proportion of the population and the velocity of their movement northwards. Both effects suggest that connectivity from the northern Ross Sea into the SPB may be considerably higher than the simulations suggest, reinforcing Hanchet et al.'s (2008) hypothesis.

\section{Closing the life cycle: hydrography and life history}

Connectivity from the Pacific-Antarctic Ridge is necessary to complete the life cycle, and Hanchet et al. (2008) hypothesized that some larvae are advected southwards to settle in the western Ross Sea. However, this solution is constrained by the hydrography. AASW flows cyclonically in the Ross Gyre and forms a thick layer within the Antarctic Slope Current (Orsi and Wiederwohl 2009). The current flows strongly east of the
Iselin Bank, and the layer penetrates farther west, forming a potential barrier to movement southward into the northern Ross Sea; rather than southward, the slope current is likely to transport early stages westward to where it intensifies close to Cape Adare (e.g., Rickard et al. 2010). As a result, the supply of young stages along the southward pathways suggested by Hanchet et al. (2008) may be relatively small.

Alternatively, Hanchet et al. (2008) predicted transport of young stages eastward in the Ross Gyre to the eastern Ross Sea. Near Cape Colbeck, AASW branches south corresponding to the Antarctic Coastal Current, providing a transport pathway on to the eastern shelf (Stover 2006; Orsi and Wiederwohl 2009). Our simulations predicted that larvae arriving in AASW off the eastern shelf would be transported inshore along the Whales and Little America troughs. Equally important, they predicted that others would be advected to the northern shelf break and along the Glomar Challenger Trough to areas where juveniles are caught in the southwestern Ross Sea. Moreover, the large proportions of particles reaching all four destinations suggested that advection in eastward pathways in the Ross Gyre to Cape Colbeck may be dominant in the supply of young stages to the Ross Sea. 
Table 5. Proportions of drifters released during particle simulations from the eastern continental slope, Drygalski Basin, Glomar Challenger (GC) Basin, and eastern Ross Sea shelf that reached destination boxes in the western Ross Sea (WRS), central Ross Sea (CRS), eastern Ross Sea (ERS), continental slope of the northern Ross Sea (NRS), western boundary of the model domain along the northern Ross Sea continental slope (WSP), northern boundary of the model domain in the western Southeast Pacific Basin (NSP).

\begin{tabular}{lcccccccc}
\hline & \multicolumn{7}{c}{ Percentage reaching: } \\
\cline { 7 - 9 } Release & Depth $(\mathrm{m})$ & No. & WRS & CRS & ERS & NRS & WSP & NSP \\
\hline Early life & & & & & & & \\
Continental Slope & Surface & 144 & 15 & 28 & 17 & 20 & - & - \\
Continental Slope & 100 & 144 & 09 & 19 & 14 & 15 & - & - \\
Continental Slope & 300 & 144 & 08 & 10 & 12 & 15 & - & - \\
Juvenile & & & & & & & & \\
Drygalski Basin & 100 & 228 & - & 13 & 0 & 30 & 36 & 1 \\
Drygalski Basin & 400 & 228 & - & 9 & 0 & 40 & 45 & 1 \\
Drygalski Basin & Bottom & 456 & - & 10 & 0 & 39 & 48 & 2 \\
GC Basin & Bottom & 672 & 17 & - & 0 & 23 & 27 & 31 \\
Eastern Ross Sea & Bottom & 360 & 7 & 43 & - & 33 & 32 & 16 \\
Adult & & & & & & & & \\
Continental Slope & 500 & 144 & 4 & 9 & 8 & 22 & 22 & 21 \\
Continental Slope & 1000 & 144 & 3 & 10 & 10 & 18 & 16 & 24 \\
\hline
\end{tabular}

Note: Counts included all particles occurring in destination boxes at some point in their 400-day trajectory, and the sum of the percentages can be greater than $100 \%$.

The same may be true for adults. Hanchet et al. (2008) hypothesized that spent adults return to the continental slope in postspawning migrations. However, strong gravity currents down the continental slope make return transport unfeasible in the bottom layer. Above, CDW forms a tongue along the flow of the southern limb of the Ross Gyre with progressively attenuated characteristics as far west as Cape Adare. Although poleward inflows of MCDW occur from the shelf break along the Drygalski and Joides troughs, they are attenuated by mixing with northward flowing Shelf Water, constraining the numbers of toothfish that can be transported southward.

Alternatively, active countercurrent migration may explain adult connectivity from the SPB into the Ross Sea. This may also explain returns on the Ross Sea shelf, including from Terra Nova Bay, of fish tagged along the continental slope (Dunn et al. 2007). However, tag returns give no information on trajectories between mark and recapture, and connectivity achieved exclusively through active movement does not resolve the contradictory physiological evidence, or the adult distributions found by Yukhov $(1970,1971)$ in sperm whale stomachs along the northern arm of the Ross Gyre. Moreover, evidence from the 2003-2005 AnSlope program indicated that the gravity current down the slope from the mouth of the Drygalski Trough occurs on a short tidal cycle and is very strong, approaching $1.5 \mathrm{~m} \cdot \mathrm{s}^{-1}$ (Gordon et al. 2004, 2009). Off the Drygalski Trough at least, the currents increase in thickness from $100 \mathrm{~m}$ at the shelf break to $400 \mathrm{~m}$ on the upper slope at $1200 \mathrm{~m}$ depth (Gordon et at. 2009), the part of the water column on the slope where the fish are mostly found. Such currents almost certainly make countercurrent swimming ineffective. The intrusions of CDW onto the shelf through the Joides and Drygalski troughs (Orsi and Wiederwohl 2009) may support active movement, but the core of these intrusions is between 250 and $450 \mathrm{~m}$ (Gordon et al. 2009), shallow relative to where adult fish are mostly taken.

Instead, our simulations suggest that ocean circulation could facilitate adult connectivity from the SPB to the Ross Sea along the southern limb of the Ross Gyre. The large proportion of particles released at $1000 \mathrm{~m}$ from the eastern slope that reach the northern boundary of the model domain indicate that the pathway may be important even without incorporating behavior. Indeed, only minor differences in behavior may substantially increase rates of connectivity. Although not necessarily exclusive, transport in deeper water by the Ross Gyre would account for the adult toothfish found in sperm whale stomachs downstream of the Pacific-Antarctic Ridge, as well as the fish tagged in McMurdo Sound and recovered in the Amundsen Sea. It would also account for the large numbers of adult fish on the Iselin Bank, transported there in the western boundary current northwards along the Ross Sea slope.

A life cycle structured in this way by the large-scale circulation would explain other features of toothfish biology that currently appear incongruous. It would account for their high fecundity, large eggs with substantial energy reserves, and long pelagic larval phase. Further, it would explain the predominance of white muscle in older stages and labriform swimming, as well as the evidence from brain morphology and condition factor that supports migration. In this context, ontogenetic changes in depth and buoyancy can be seen as adaptive, facilitating movement between spawning and feeding grounds in adults and from spawning areas to juvenile grounds in young stages, but constraining juveniles to areas where appropriate prey species are concentrated and from where the circulation will result in transport to adult areas as they become neutrally buoyant. 


\section{Complex population structure and marine protected areas}

Membership in a population requires being in the appropriate place throughout the life cycle; otherwise fish are lost from their population, either to mortality or to become vagrants (Sinclair and Iles 1989). In consequence, selection acts strongly to reinforce spatial life cycle trajectories that successful spawners must follow in order for their progeny to recruit to the population. Nevertheless, prevailing transport may lead to local abundances of juveniles in places where they cannot access adult areas (e.g., Beck et al. 2003). In the southwestern Ross Sea, our particle simulations predicted transport of newly buoyant fish northwards along the Drygalski Trough, but then westward along the shelf away from the Adare Basin. The circulation model may overestimate transport along the shelf compared with downslope because of its lack of tidal forcing. Biological interactions may also play an important role; small differences in behaviour, amplified by the circulation, may modify migration pathways. However, the trajectories were corroborated by the high proportions of juveniles we found north of the Drygalski Trough and off Cape Adare. Although the boundary of our circulation model limits more detailed examination of trajectories farther westward, fish emerging from the Drygalski Trough and entrained in gravity currents downslope would be transported into the deep western boundary current along the continental slope to the southeastern Indian Ocean. As a result, the southern part of the Drygalski Trough may only partially supply the Adare Basin.

Transport northwards along the Joides Trough might form an alternate pathway from the southern Ross Sea to the Adare Basin; however, we found a lack of drifters moving in this direction. Instead, outflows of deeper water from the eastern Ross Sea, notably from the Glomar Challenger Trough, contribute to the deep western boundary current flowing northwards along the continental slope into the SPB and around the Iselin Bank into the Adare Basin (Orsi and Wiederwohl 2009). Juvenile areas connected directly by transport pathways to the Ross Gyre via these deep outflows may be more important in supplying spawning areas on the Pacific-Antarctic Ridge and hence represent the critical life cycle trajectories on which the Ross Sea population depends. By contrast, fish from the southwestern Ross Sea transported along the Drygalski Trough may be important to the local ecosystem, but represent a life cycle trajectory of secondary importance to the Ross Sea population; leaving the western Ross Sea via gravity currents from the mouth of the Drygalski Trough, they may follow a path similar to the salty Bottom Water created at the edge of the Ross Sea, which spreads westward between the continental slope and the Balleny Ridge into the Australian-Antarctic Basin (Orsi et al. 1999). In this way, the southwestern Ross Sea may supply immigrants to areas in the southern Indian Ocean.

Life cycle trajectories structured by the large-scale circulation may define a population and its gene flow, as well as its dynamics. In toothfish, genetic data differentiated fish taken from sampling areas in the Ross Sea from others west of Prydz Bay, as well as from the Antarctic Peninsula (Kuhn and Gaffney 2008). Changes in the large-scale circulation may have important and long-lasting effects by altering connectivity along these trajectories. Indeed, tectonic change implicated in the development of the ACC and the Ross Gyre may ultimately drive the separation of life cycles that define toothfish population structure in the Southern Ocean. The implica- tions are profoundly important for fishery management. With a life cycle tied to the Ross Gyre, most successfully spawning fish may pass during their life history through an area around the Iselin Bank where fishing effort is currently concentrated. An MPA risks protecting what may be relatively unimportant juvenile and adult feeding areas in the southwestern Ross Sea while covering only parts of the life cycle critical to the targeted population. Yet benefits of protecting areas in the western Ross Sea may accrue to areas in the southern Indian Ocean by promoting emigration rates along the continental shelf and slope west out of the Drygalski Trough. By integrating age studies, otolith chemistry, and particle simulations in a multidisciplinary approach that incorporates hydrography, we can construct and test spatially explicit hypotheses like these, which relate life history connectivity to the physical circulation of oceanic systems.

\section{Acknowledgements}

We thank personnel from the NOAA Antarctic Marine Living Resources Program (AMLR) and CCAMLR who organized and sampled the otoliths. The Woods Hole Oceanographic Institution kindly made available their Plasma Mass Spectrometry Facility, and Scot Birdwhistell provided technical support. Cynthia Jones, Director of CQFE at Old Dominion University, was instrumental in her advice and encouragement. John Klinck, Director of CCPO at Old Dominion University, Christian Reiss, currently at NOAA AMLR, and Patrick Gaffney and Kristen Kuhn at the University of Delaware also gave valuable insights and advice. Stuart Hanchet gave permission for use of the map and schematic in Fig. 1, and Christina Stover-Wiederwohl provided the bathymetry shown in Fig. 2a. Funding was through the United States National Science Foundation (NSF-OPP-0338294) and NOAA AMLR; support for M. Dinniman and E. Hofmann was provided by ANT-0944174.

\section{References}

Abramowitz, M., and Stegun, I.A. 1964. Handbook of mathematical functions with formulas, graphs, and mathematical tables. Tenth Printing AMS IA - National Bureau of Standards Applied Mathematics Series. Vol. 55. National Bureau of Standards, Washington, D.C.

Ainley, D.G. 2010. A history of the exploitation of the Ross Sea, Antarctica. Polar Rec. (Gr. Brit.), 46(03): 233-243. doi:10.1017/ S003224740999009X.

-Ashford, J.R., and Jones, C.M. 2007. Oxygen and carbon stable isotopes in otoliths record spatial isolation of Patagonian toothfish (Dissostichus eleginoides). Geochim. Cosmochim. Acta, 71(1): 87-94. doi:10.1016/j.gca.2006.08.030.

-Ashford, J.R., Jones, C.M., Hofmann, E.E., Everson, I., Moreno, C., Duhamel, G., and Williams, R. 2005. Can otolith elemental signatures record the capture site of Patagonian toothfish (Dissostichus eleginoides), a fully marine fish in the Southern Ocean? Can. J. Fish. Aquat. Sci. 62(12): 2832-2840. doi:10.1139/f05-191.

-Ashford, J.R., Arkhipkin, A.I., and Jones, C.M. 2006. Can the chemistry of otolith nuclei determine population structure of Patagonian toothfish, Dissostichus eleginoides? J. Fish Biol. 69(3): 708-721. doi:10.1111/j.1095-8649.2006.01144.x.

-Ashford, J.R., Arkhipkin, A.I., and Jones, C.M. 2007. Otolith chemistry reflects frontal systems in the Antarctic Circumpolar Current. Mar. Ecol. Prog. Ser. 351: 249-260. doi:10.3354/meps07153. 
-Ashford, J.R., Jones, C.M., Hofmann, E.E., Everson, I., Moreno, C.A., Duhamel, G., and Williams, R. 2008. Otolith chemistry indicates population structuring by the Antarctic Circumpolar Current. Can. J. Fish. Aquat. Sci. 65(2): 135-146. doi:10.1139/f07-158.

-Ashford, J.R., La Mesa, M., Fach, B.A., Jones, C., and Everson, I. 2010. Testing early life connectivity using otolith chemistry and particle-tracking simulations. Can. J. Fish. Aquat. Sci. 67(8): 1303-1315. doi:10.1139/F10-065.

-Ashford, J.R., Fach, B.A., Arkhipkin, A.I., and Jones, C.M. 2012. Testing early life connectivity supplying a marine fishery around the Falkland Islands. Fish. Res. 121-122: 144-152. doi:10.1016/ j.fishres.2012.01.023.

Beck, M.W., Heck, K.L., Able, K.W., Childers, D.L., Eggleston, D.B., Gillanders, B.M., Halpern, B.S., Hays, C.G., Hoshino, K., Minello, T.J., Orth, R.J., Sheridan, P.F., and Weinstein, M.P. 2003. The role of nearshore ecosystems as fish and shellfish nurseries. Issues in Ecology No. 11, Ecological Society of America.

Bromwich, D.H., Monaghan, A.J., Manning, K.W., and Powers, J.G. 2005. Real-time forecasting for the Antarctic: an evaluation of the Antarctic Mesoscale Prediction System (AMPS). Mon. Weather Rev. 133(3): 579-603. doi:10.1175/MWR-2881.1.

Brooks, C.M. 2008. Radiometric age validation and spatial distribution of the Antarctic toothfish, Dissostichus mawsoni: implications for a deep-sea Antarctic fishery. M.S. thesis, California State University, Monterey Bay, Moss Landing Marine Laboratories, Moss landing, California.

Brooks, C.M., Andrews, A.H., Ashford, J.R., Ramanna, N., Jones, C.D., Lundstrom, C., and Cailliet, G.M. 2011. Age estimation and lead-radium dating of Antarctic toothfish (Dissostichus mawsoni). Polar Biol. 34(3): 329-338. doi:10.1007/s00300-010-0883-z.

CCAMLR. 2006. Scientific observer's manual. Commission of the Convention for the Conservation of Antarctic Marine Living Resources, Hobart, Australia.

CCAMLR. 2007. Statistical Bulletin 19 (1997-2006). Commission of the Convention for the Conservation of Antarctic Marine Living Resources, Hobart, Australia.

Chen, Z., Canil, D., and Longerich, H.P. 2000. Automated in situ trace element analysis of silicate materials by laser ablation inductively coupled plasma mass spectrometry. Fresnius'. J. Anal. Chem. 368: 73-78. PMID:11220835.

DeVries, A.L., Ainley, D.G., and Ballard, G. 2008. Decline of the Antarctic toothfish and its predators in McMurdo Sound and the southern Ross Sea, and recommendations for restoration. CCAMLR Scientific Papers WG-EMM 08/XX.

Dinniman, M.S., Klinck, J.M., and Smith, W.O., Jr. 2003. Cross-shelf exchange in a model of the Ross Sea circulation and biogeochemistry. Deep Sea Res. Part II Top. Stud. Oceanogr. 50(22-26): 31033120. doi:10.1016/j.dsr2.2003.07.011.

Dinniman, M.S., Klinck, J.M., and Smith, W.O., Jr. 2011. A model study of Circumpolar Deep Water on the West Antarctic Peninsula and Ross Sea continental shelves. Deep Sea Res. Part II Top. Stud. Oceanogr. 58(13-16): 1508-1523. doi:10.1016/j.dsr2.2010.11.013.

Dunn, A., Hanchet, S.M., and Ballara, S. 2007. An unpdated descriptive analysis of the toothfish (Dissostichus sp.) tagging program in Subareas 88.1 and 88.2 for 2006/07. CCAMLR Scientific Papers WG-SAM-07/05.

-Eastman, J.T., and Lannoo, M.J. 2011. Divergence of brain and retinal anatomy and histology in pelagic Antarctic notothenoid fishes of the sister taxa Dissostichus and Pleuragramma. J. Morphol. 272(4): 419-441. doi:10.1002/jmor.10926. PMID: 21246598.
-Fach, B.A., and Klinck, J.M. 2006. Transport of Antarctic krill (Euphausia superba) across the Scotia Sea. Part I: Circulation and particle tracking simulations. Deep Sea Res. Part I Oceanogr. Res. Pap. 53(6): 987-1010. doi:10.1016/j.dsr.2006.03.006.

Fenaughty, J.M. 2006. Geographical differences in the condition, reproductive development, sex ratio, and length distribution of Antarctic toothfish Dissostichus mawsoni from the Ross Sea, Antarctica (CCAMLR Statistical Subarea 88.1). CCAMLR Sci. 13: 27-45.

Fenaughty, J.M., Eastman, J.T., and Sidell, B.D. 2008. Biological implications of low condition factor "axe handle" specimens of the Antarctic toothfish, Dissostichus mawsoni, from the Ross Sea. Antarct. Sci. 20(6): 537-551. doi:10.1017/S0954102008001430.

Gordon, A.L., Zambianchi, E., Orsi, A., Visbeck, M., Giulivi, C., Whitworth, T., III, and Spezie, G. 2004. Energetic plumes over the western Ross Sea continental slope. Geophys. Res. Lett. 31(21): L21302. doi:10.1029/2004GL020785.

Gordon, A.L., Orsi, A.H., Muench, R., Huber, B.A., Zambianchi, E., and Visbeck, M. 2009. Western Ross Sea continental slope gravity currents. Deep Sea Res. Part II Top. Stud. Oceanogr. 56(13-14): 796-817. doi:10.1016/j.dsr2.2008.10.037.

Haidvogel, D.B., Arango, H., Budgell, W.P., Cornuelle, B.D., Curchitser, E., Di Lorenzo, E., Fennel, K., Geyer, W.R., Hermann, A.M., Lanerolle, L., Levin, J., McWilliams, J.C., Miller, A.J., Moore, A.M., Powell, T.M., Shchepetkin, A.F., Sherwood, C.R., Signell, R.P., Warner, J.C., and Wilkin, J. 2008. Ocean forecasting in terrain-following coordinates: formulation and skill assessment of the Regional Ocean Modeling System. J. Comput. Phys. 227(7): 3595-3624. doi:10.1016/j.jcp.2007.06.016.

Hamming, R.W. 1973. Numerical methods for scientists and engineers. 2nd ed. McGraw-Hill, New York.

Hanchet, S.M. 2010. Updated species profile for Antarctic toothfish (Dissostichus mawsoni). CCAMLR Scientific Papers WF-FSA$10 / 24$.

Hanchet, S.M., Rickard, G.J., Fenaughty, J.M., Dunn, A., and Williams, M.J. 2008. A hypothetical life cycle for Antarctic toothfish Dissostichus mawsoni in Antarctic waters of CCAMLR Statistical Area 88. CCAMLR Sci. 15: 35-54.

Horn, P.L. 2002. Age and growth of Patagonian toothfish (Dissostichus eleginoides) and Antarctic toothfish (D. mawsoni) in waters from the New Zealand subantarctic to the Ross Sea, Antarctica. Fish. Res. 56(3): 275-287. doi:10.1016/S0165-7836(01)00325-3.

-Hunter, J.R., Craig, P.D., and Philips, H.E. 1993. On the use of random walk models with spatially variable diffusivity. J. Comput. Phys. 106: 366-376.

Ihssen, P.H., Booke, H.E., Casselman, J.M., McGlade, J.M., Payne, N.R., and Utter, F.M. 1981. Stock identification: materials and methods. Can. J. Fish. Aquat. Sci. 38(12): 1838-1855. doi: 10.1139/f81-230.

Jones, C.M., and Chen, Z. 2003. New techniques for sampling larval and juvenile fish otoliths for trace-element analysis with laser-ablation sector-field inductively-coupled plasma mass spectrometry (SF-ICPMS). In Proceedings of the 26th Annual Larval Fish Conference, Institute of Marine Research, Bergen, Norway. pp. 431-443.

Khattree, R., and Naik, D.N. 1999. Applied multivariate statistics with SAS software. 2nd ed. SAS Institute Inc., Cary, North Carolina, and John Wiley \& Sons, New York.

Khattree, R., and Naik, D.N. 2000. Multivariate data reduction and discrimination with SAS software. SAS Institute Inc., Cary, North Carolina, and John Wiley \& Sons, New York.

Kuehl, R.O. 1994. Statistical principles of research design and analysis. Duxbury Press, Belmont, California. 
Kuhn, K.L., and Gaffney, P.M. 2008. Population subdivision in the Antarctic toothfish (Dissostichus mawsoni) revealed by mitochondrial and nuclear single nucleotide polymorphisms (SNPs). Antarct. Sci. 20(04): 327-338. doi:10.1017/S0954102008000965.

La Mesa, M. 2007. The utility of otolith microstructure in determining the timing and position of the first annulus in juvenile Antarctic toothfish (Dissostichus mawsoni) from the South Shetland Islands. Polar Biol. 30(10): 1219-1226. doi:10.1007/s00300-007-0281-3.

Locarnini, R.A. 1994. Water masses and circulation in the Ross Gyre and environs. Ph.D. dissertation, Texas A\&M University, College Station, Texas.

Near, T.J., Russo, S.E., Jones, C.D., and DeVries, A.L. 2003. Ontogenetic shift in buoyancy and habitat in the Antarctic toothfish, Dissostichus mawsoni (perciformes: Nototheniidae). Polar Biol. 26: $124-128$.

Orsi, A.H., and Wiederwohl, C.L. 2009. A recount of Ross Sea waters. Deep Sea Res. Part II Top. Stud. Oceanogr. 56(13-14): 778-795. doi:10.1016/j.dsr2.2008.10.033.

Orsi, A.H., Whitworth, T., III, and Nowlin, W.D., Jr. 1995. On the meridional extent and fronts of the Antarctic Circumpolar Current. Deep Sea Res. Part I Oceanogr. Res. Pap. 42(5): 641-673. doi: 10.1016/0967-0637(95)00021-W.

-Orsi, A.H., Johnson, G.C., and Bullister, J.L. 1999. Circulation, mixing and production of Antarctic Bottom Water. Prog. Oceanogr. 43(1): 55-109. doi:10.1016/S0079-6611(99)00004-X.

Padman, L., Howard, S.L., Orsi, A.H., and Muench, R.D. 2009. Tides of the northwestern Ross Sea and their impact on dense outflows of Antarctic Bottom Water. Deep Sea Res. Part II Top. Stud. Oceanogr. 56(13-14): 818-834. doi:10.1016/j.dsr2.2008.10.026.

Popper, K. 1959. The logic of scientific discovery. Hutchinson, London, UK.

Powers, J.G., Monaghan, A.J., Cayette, A.M., Bromwich, D.H., Kuo, Y.H., and Manning, K.W. 2003. Real-time mesoscale modeling over Antarctica: The Antarctic Mesoscale Prediction System (AMPS). Bull. Am. Meteorol. Soc. 84(11): 1533-1545. doi: 10.1175/BAMS-84-11-1533.

-Rickard, G.J., Roberts, M.J., Williams, M.J.M., Dunn, A., and Smith, M.H. 2010. Mean circulation and hydrography in the Ross Sea sector, Southern Ocean: representation in numerical models. Antarct. Sci. 22(5): 533-558. doi:10.1017/S0954102010000246.

Roberts, C.M., Bohnsack, J.A., Gell, F., Hawkins, J.P., and Goodridge, R. 2001. Effects of marine reserves on adjacent fisheries. Science,
294(5548): 1920-1923. doi:10.1126/science.294.5548.1920. PMID: 11729316.

Shchepetkin, A.F., and McWilliams, J.C. 2005. The regional oceanic modeling system (ROMS): a split-explicit, free-surface, topography following coordinate ocean model. Ocean Model. 9(4): 347404. doi:10.1016/j.ocemod.2004.08.002.

Shchepetkin, A.F., and McWilliams, J.C. 2009. Correction and commentary for "Ocean forecasting in terrain-following coordinate: Formulation and skill assessment of the regional ocean modeling system" by Haidvogel et al. J. Comp. Phys. 227, pp. 3595-3634. J. Comput. Phys. 228(24): 8985-9000. doi:10.1016/j.jcp.2009. 09.002.

Sinclair, M., Iles, T.D. 1989. Population regulation and speciation in the oceans. J. Cons. Cons. Int. Explor. Mer, 45: $165-175$.

-Smith, D.A., Hofmann, E.E., Klinck, J.M., and Lascara, C.M. 1999. Hydrography and circulation of the West Antarctic Peninsula Continental Shelf. Deep Sea Res. Part I Oceanogr. Res. Pap. 46(6): 925-949. doi:10.1016/S0967-0637(98)00103-4.

Stover, C.L. 2006. A new account of Ross Sea waters: characteristics, volumetrics, and variability. M.S. thesis, Texas A\&M University, College Station, Texas.

Thorpe, S.E., Murphy, E.J., and Watkins, J.L. 2007. Circumpolar connections between Antarctic krill (Euphausia superba Dana) populations: investigating the roles of ocean and sea ice transport. Deep Sea Res. Part I Oceanogr. Res. Pap. 54(5): 792-810. doi: 10.1016/j.dsr.2007.01.008.

-Visser, A.W. 1997. Using random walk models to simulate the vertical distribution of particles in a turbulent water column. Mar. Ecol. Prog. Ser. 158: 275-281. doi:10.3354/meps158275.

-Watwood, S.L., Miller, P.J.O., Johnson, M., Madsen, P.T., and Tyack, P.L. 2006. Deep-diving foraging behaviour of sperm whales (Physeter macrocephalus). J. Anim. Ecol. 75(3): 814-825. doi: 10.1111/j.1365-2656.2006.01101.x. PMID:16689963.

-Whitworth, T., III, and Orsi, A.H. 2006. Antarctic Bottom Water production and export by tides in the Ross Sea. Geophys. Res. Lett. 33(12): L12609. doi:10.1029/2006GL026357.

Yukhov, V.L. 1970. New data on the distribution and biology of the Dissostichus mawsoni Norman in the Antarctic high latitudes. J. Ichthyol. 10: 422-424.

Yukhov, V.L. 1971. The range of Dissostichus mawsoni Norman and some features of its biology. J. Ichthyol. 11: 8-18. 


\section{This article has been cited by:}

1. Mario La Mesa, Andrea Piñones, Barbara Catalano, Julian Ashford. 2015. Predicting early life connectivity of Antarctic silverfish, an important forage species along the Antarctic Peninsula. Fisheries Oceanography 24:10.1111/fog.2015.24.issue-2, 150-161. [CrossRef]

2. Guoping Zhu, Min Zhang, Julian Ashford, Xiaorong Zou, Xinjun Chen, Yingqi Zhou. 2014. Does life history connectivity explain distributions of Chilean jack mackerel Trachurus murphyi caught in international waters prior to decline of the southeastern Pacific fishery?. Fisheries Research 151, 20-25. [CrossRef]

3. Peter A. Abrams. 2014. How precautionary is the policy governing the Ross Sea Antarctic toothfish (Dissostichus mawsoni) fishery?. Antarctic Science 26, 3-14. [CrossRef]

4. Mario La Mesa, Emilio Riginella, Carlotta Mazzoldi, Julian Ashford. 2014. Reproductive resilience of ice-dependent Antarctic silverfish in a rapidly changing system along the Western Antarctic Peninsula. Marine Ecology n/a-n/a. [CrossRef]

5. RR Hoover, CM Jones. 2013. Effect of laser ablation depth in otolith life history scans. Marine Ecology Progress Series 486, 247-256. [CrossRef] 